\title{
CARINHOSO, DE PIXINGUINHA, PARA VIOLA DE 10 CORDAS SOLO: ARRANJO E ANÁLISE
}

\section{CARINHOSO, BY PIXINGUINHA, FOR 10 STRINGS SOLO VIOLA: ARRANGEMENT AND ANALYSIS}

\author{
Prof. Dr. Marcus Ferrer \\ Escola de Música \\ Universidade Federal do Rio de Janeiro \\ marcusferrer@uol.com.br
}

\section{Resumo}

A viola vem se desenvolvendo no Brasil ao longo de cinco séculos e tem participado/ajudado na construção das tradições culturais do país. Além do vasto repertório já consolidado, nosso olhar volta-se para outros ambientes culturais/musicais e procura testar, basicamente por meio de composições, de arranjos e de transcrições, a possibilidade utilização deste instrumento. Neste artigo, apresentaremos uma das linhas/ambientes com os quais temos lidado, como foco de nossa pesquisa com a viola - o Choro, com um arranjo da obra Carinhoso, de Pixinguinha.

Palavras-chave: Viola de 10 cordas; Choro; Arranjo; Análise.

\section{Abstract}

The viola has been developing in Brazil for five centuries and has participated/helped in the construction of the country's cultural traditions. In addition to the vast repertoire already consolidated, our focus turns to other cultural/musical environments and seeks to test, basically through compositions, arrangements and transcriptions, the possibility of using this instrument. In this article, we will present one of the lines/ environments with which we have dealt, as the focus of our research with the viola - the Choro, with an arrangement of the work Carinhoso, by Pixinguinha.

Keywords: 10-String Viola; Choro; Arrangement; Analysis. 


\section{Lista de Figuras e de Exemplos musicais}

Figura 1. Nomenclatura da viola. (fonte: Moura e Freitas ,2000 , p.9).

Figura 2. Conhecendo a viola. (fonte: Araújo, 1999, p. 10).

Figura 3. Anatomia da viola. (fonte: Viola, [s.d.], p. 10).

Exemplo musical 1. Afinação Rio abaixo (Sol maior).

Exemplo musical 2. Extensão em Rio abaixo.

Exemplo musical 3. Cinco pares de cordas.

Exemplo musical 4. Notação musical da afinação Rio abaixo (Sol maior).

Exemplo musical 5. Resultado sonoro da notação de dois acordes. (fonte: arranjo de "Carinhoso").

Exemplo musical 6. Notação normal e as cordas oitavadas.

Exemplo musical 7. Transposição.

Exemplo musical 8. Transposição.

Exemplo musical 9. Mudança rítmica da melodia.

Exemplo musical 10. Mudança rítmica da melodia.

Exemplo musical 11. Mudança rítmica da melodia.

Exemplo musical 12. Mudança rítmica da melodia.

Exemplo musical 13. Mudança rítmica da melodia.

Exemplo musical 14. Mudança rítmica da melodia.

Exemplo musical 15. Mudança rítmica da melodia.

Exemplo musical 16. Mudança rítmica da melodia. 
Exemplo musical 17. Mudança rítmica da melodia.

Exemplo musical 18. Mudança rítmica da melodia.

Exemplo musical 19. Esquema das mudanças rítmicas da melodia.

Exemplo musical 20. Alterações na melodia original.

Exemplo musical 21. Alterações na melodia original.

Exemplo musical 22. Dobramento de terça.

Exemplo musical 23. Dobramento de terça.

Exemplo musical 24. Dobramento de terça.

Exemplo musical 25. Dobramento de terça.

Exemplo musical 26. Dobramento de terça.

Exemplo musical 27. Dobramento de terça.

Exemplo musical 28. Dobramento de sexta.

Exemplo musical 29. Contração melódica.

Exemplo musical 30. Contração melódica.

Exemplo musical 31. Ornamentos.

Exemplo musical 32. Mudanças na harmonia.

Exemplo musical 33. Mudanças na harmonia.

Exemplo musical 34. Mudanças na harmonia.

Exemplo musical 35. Mudanças na harmonia.

Exemplo musical 36. Mudanças na harmonia.

Exemplo musical 37. Mudanças na harmonia.

\section{6}


Exemplo musical 38. Mudanças na harmonia.

Exemplo musical 39. Mudanças na harmonia.

Exemplo musical 40. Mudanças na harmonia.

Exemplo musical 41 . Mudanças na harmonia.

Exemplo musical 42. Mudanças na harmonia.

Exemplo musical 43. Mudanças na harmonia.

Exemplo musical 44. Mudanças na harmonia..

Exemplo musical 45. Referências extra-partitura.

Exemplo musical 46. Referências extra-partitura.

Exemplo musical 47. Referências extra-partitura.

Exemplo musical 48. Referências extra-partitura.

Exemplo musical 49. Referências extra-partitura.

Exemplo musical 50. Referências extra-partitura.

Exemplo musical 51. Referências extra-partitura.

Exemplo musical 52. Referências extra-partitura.

Exemplo musical 53. Referências extra-partitura.

Exemplo musical 54. Forma. 


\section{Introdução}

Apresentamos neste artigo uma proposta de inserção da viola de 10 cordas na prática interpretativa do Choro. Para compreendermos se é possivel construir uma ponte entre a viola e o Choro, elaboramos o arranjo da obra "Carinhoso", de Pixinguinha (Alfredo da Rocha Vianna). Para que possamos demonstrar de forma consistente o resultado dessa proposta, utilizamos a análise musical como ferramenta.

Tendo como partida uma relação afetiva com este instrumento' e uma vontade de contribuir para um alargamento de seus horizontes, muitas vezes, o interesse por ele tem sido direcionado para outros ambientes musicais diferentes da chamada música caipira e/ou sertaneja, e das manifestações das festas populares. Essa intenção de ultrapassar o seu meio musical mais tradicional tem como referência a história do desenvolvimento do violão. Este instrumento conseguiu transpor barreiras e transformar-se em um instrumento polivalente, rico em possibilidades e que, atualmente, pode ser utilizado para interpretar praticamente qualquer tipo de música, seja solo ou de câmera, popular, erudita ou contemporanea. Tal característica permitiu que ele se disseminasse em todas as camadas sociais e em países com culturas totalmente diferentes. Como resultado, afora sua popularidade e sobrevivencia ao longo de séculos, temos uma enorme quantidade e variedade de repertório. $\bigcirc$ que nos interessa particularmente é o fato de que, enquanto uma parte desse vasto repertório seja constituído por obras escritas para o violão, uma outra parcela é formada por transcrições e arranjos. Por conseguinte, a produção de arranjos para a viola pode se definir também pela ampliação do seu universo musical.

Além da forte relação com o instrumento, mais dois outros fatores foram determinantes para a realização do arranjo: nossa experiência de cerca de trinta anos com o Choro² $^{2}$; a formação acadêmica em Composição ${ }^{3}$.

\footnotetext{
I Nosso primeiro contato com a viola deu-se ainda na infância na casa dos avós, em São Lourenço, Sul de Minas Gerais, por meio das Folias de Reis. Mais tarde, no início da década de oitenta, como profissional, tocando e compondo no instrumento.

2 Como violonista de 6 e de 7 cordas, compositor e arranjador.

3 Bacharelado em Composição, Escola de Música - Universidade Federal do Rio de Janeiro. Mestrado em Composição, Escola de Música - Universidade Federal do Rio de Janeiro.
}

\section{8}

REV. TULHA, RIBEIRÃO PRETO, v. 2, n. 2, p. 94-153, jul.-dez. 2016 
Não é nossa intenção trazer para o trabalho discussões teóricas e metodológicas, comparando e discutindo os critérios adotados. As definições estão expressas de forma concisa, delimitando objetivamente 0 caminho proposto para 0 desenvolvimento do trabalho. Assim, a guisa de exemplo, ao definirmos o termo "arranjo", procuramos fazê-lo de forma mais objetiva possivel e não entramos na questão da discussão sobre outros termos correlatos como transcrição, versão e adaptação.

Ao definirmos a forma de análise e a linha comparativa de exposição, estaremos delimitando nossa metodologia. A análise foi desenvolvida sobre determinados itens definidos a partir do próprio material do arranjo.

Como já exposto no início, este trabalho de arranjo tem como finalidade demonstrar as potencialidades da viola na interpretação do Choro.

\section{A viola de 10 cordas}

A viola aqui referida, é um instrumento de estrutura semelhante ao violão, mas um pouco menor, com cinco pares de cordas. Há diversos manuais e métodos de viola que trazem algum desenho ou foto do instrumento como meio de identificação, indicando também os nomes de suas partes constituintes. Selecionamos três exemplos, retirados de métodos diferentes: "Nomenclatura da viola", de Reis Moura4; "Conhecendo a viola", de Rui Tornezes; e "Anatomia da viola", de Braz da Violab.

4 Moura, Reis \& Freitas, Marcos Villaça. Descomplicando a viola. Brasillia: ed. autor, 2000, p. 9.

5 Araújo, Rui Torneze de. Viola caipira: estudo dirigido. São Paulo: Irmãos Vitale, 1999, p. 10.

6 Viola, Braz da. Manual do violeiro. São Paulo: Ricordi, 1999, p. 10. 


\subsection{Nomenclatura}

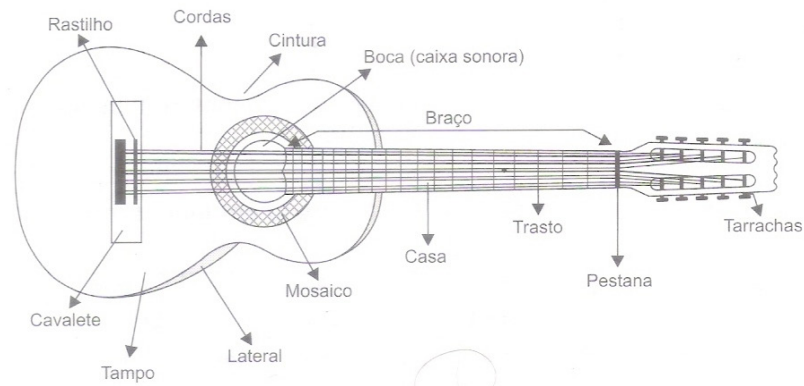

Figura 1. Nomenclatura da viola. (fonte: Moura e Freitas, 2000, p. 9).

\section{Conhecendo a Viola}

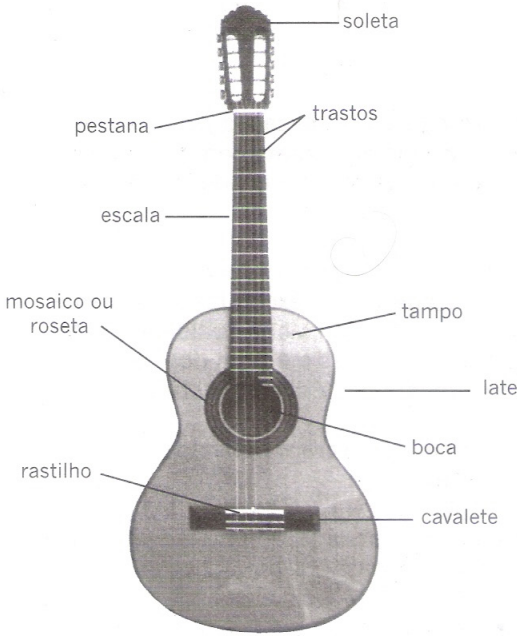

vista frontal

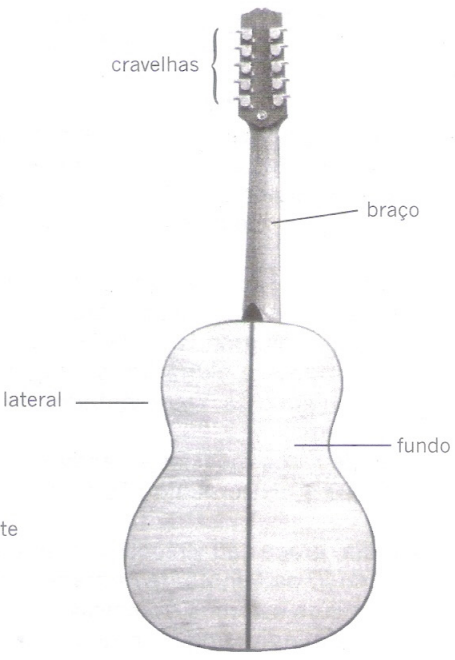

vista posterior

Figura 2. Conhecendo a viola. (fonte: Araújo, 1999, p. 10).

\section{0}

REV. TULHA, RIBEIRÃO PRETO, v. 2, n. 2, p. 94-153, jul.-dez. 2016 


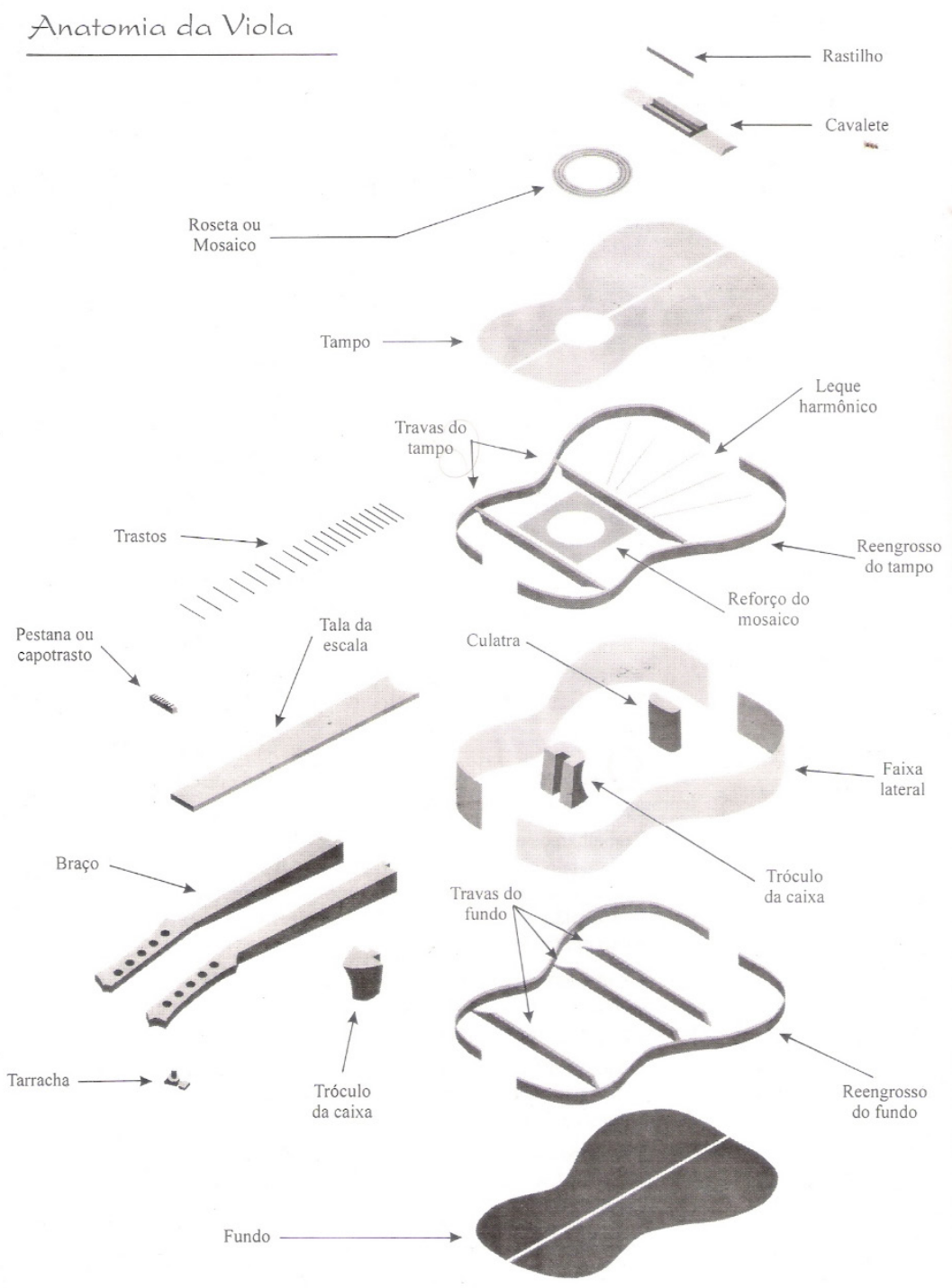

Figura 3. Anatomia da viola. (fonte: Viola, [s.d.], p. 10).

Essas três figuras mostram pequenas diferenças entre si, sendo mais acentuadas na última. A figura 3, de Brás da Viola, é a mais diferente e

\section{1}

REV. TULHA, RIBEIRÃO PRETO, v. 2, n. 2, p. 94-153, jul.-dez. 2016 
provavelmente está relacionada ao fato de o autor ser, além de violeiro, um reconhecido luthier. Ele mostra o desenho de uma viola desmontada, nomeando também as partes internas de sua construção. A viola que utilizamos é um instrumento moderno semelhante às figuras 1, 2 e 3, e, após a observação das ilustrações, torna-se clara a sua identificação.

\subsection{Afinação e Extensão}

Faz-se necessária uma definição com relação à afinação pois há uma grande variedade. Adotamos uma afinação bastante utilizada na região Centro-Sul do Brasil (Corrêa, 2000, p.33) denominada Rio abaixo (Sol maior):

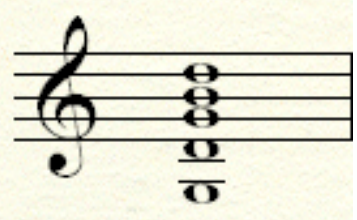

Exemplo musical 1. Afinação Rio abaixo (Sol maior).

Escolhida a afinação, a extensão fica praticamente definida. $\bigcirc$ exemplo a seguir mostra uma extensão delimitada por nós especificamente para o arranjo. Sabemos que, de acordo com as especificidades de cada instrumento, há pequenas diferenças quanto à nota mais aguda, mas de uma forma geral a extensão indicada pode ser utilizada como referência para a maioria das violas, tanto as produzidas em fábricas quanto aquelas manufaturadas por luthiers.

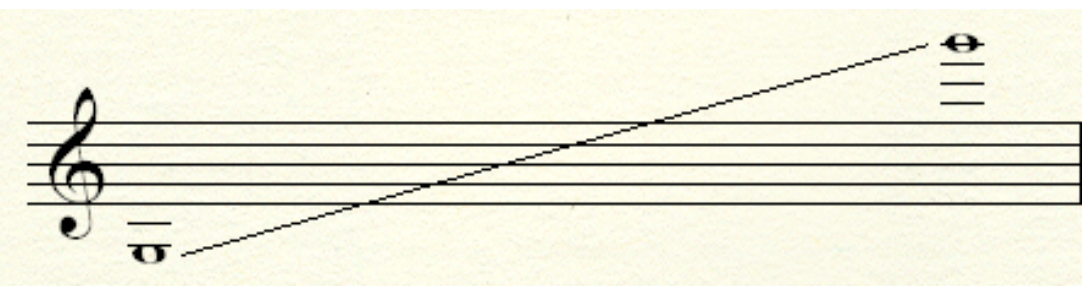

Exemplo musical 2. Extensão em Rio abaixo. 
Com respeito à escrita musical, utilizamos duas formas de notação bastante utilizadas atualmente (em conjunto ou individualmente): a cifragem alfa-numérica (cifra) e o pentagrama.

O sistema de notação por cifragem alfa-numérica não define, a priori, um instrumento específico para a sua leitura e pode ser interpretado por qualquer instrumento harmônico: viola, violão, piano, cavaquinho etc. As partituras de Choro, notadamente aquelas para instrumentos melódicos, se caracterizam pela combinação entre pentagrama e cifragem?. Em nosso artigo, não utilizaremos a notação em tablatura. Tanto o arranjo quanto a análise estarão notados em pentagrama e a cifra será também utilizada na análise.

\subsection{Notação da viola no pentagrama}

A viola é composta de cinco pares de cordas, sendo os dois primeiros pares uníssonos e os demais oitavados, como mostra o exemplo a seguir:

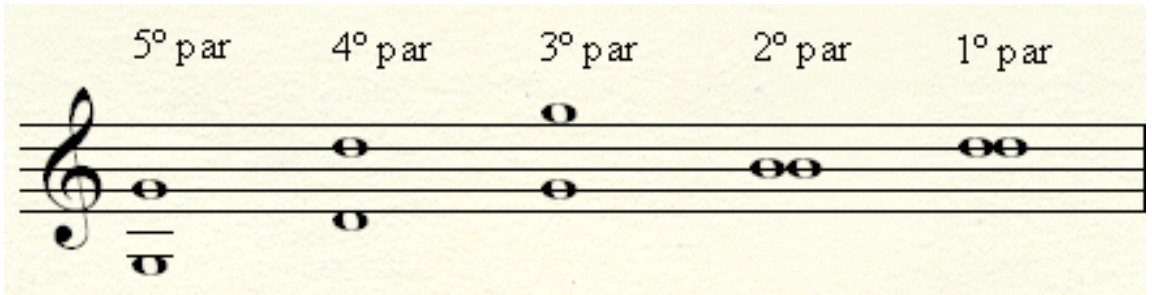

Exemplo musical 3. Cinco pares de cordas.

A notação musical deve ser feita como se cada par fosse apenas uma corda, mas tendo em mente que os três pares mais graves $\left(5^{\circ}, 4^{\circ} \mathrm{e}\right.$ $3^{\circ}$ ) estarão soando também oitavados.

7 Carneiro (2001) cita uma cifragem antiga utilizada no Choro: $1^{\circ}, 2^{\circ}, 3^{a}$ e Preparação. Respectivamente, Tônica, Dominante, SubDominante e Dominante secundária. 


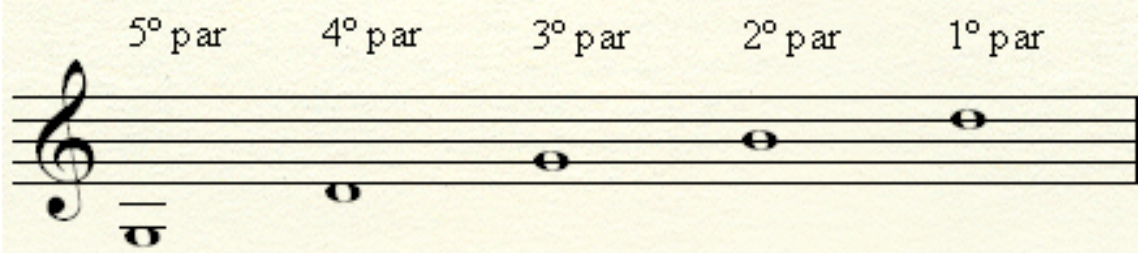

Exemplo musical 4. Notação musical da afinação Rio abaixo (Sol maior).

A seguir, mostraremos dois acordes, retirados do arranjo da obra "Carinhoso", de Pixinguinha, nos quais demonstraremos as diferenças entre a notação e o resultado sonoro de fato, decorrente da combinação das cordas oitavadas e uníssonas, e da transposição:
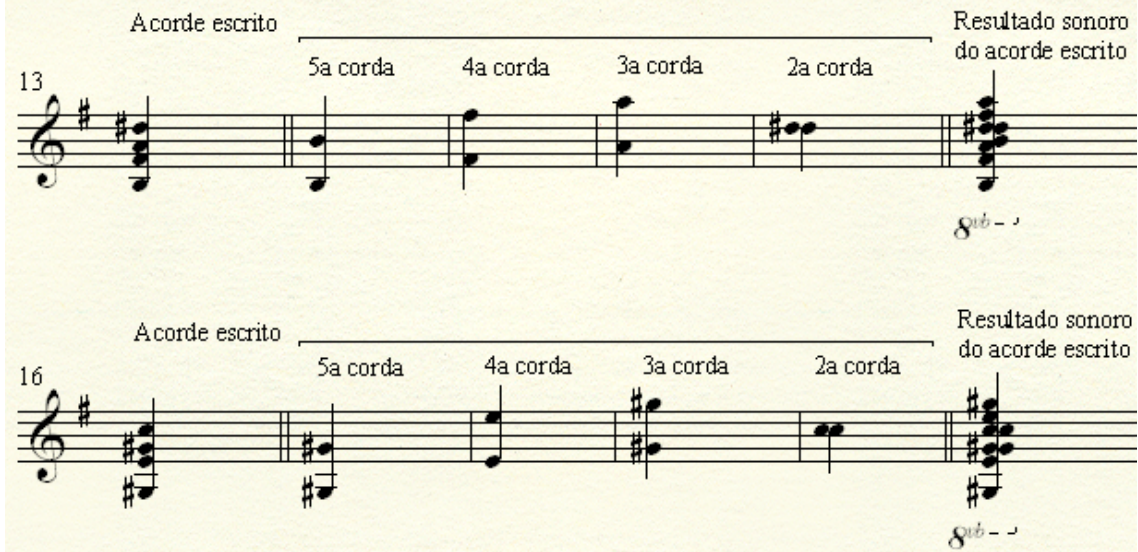

Exemplo musical 5. Resultado sonoro da notação de dois acordes. (fonte: arranjo de "Carinhoso").

\subsection{Técnicas de mão direita}

No arranjo de "Carinhoso", apenas o polegar é utilizado. 


\subsubsection{Para equilibrar o som da viola}

A viola é um instrumento com um desequilibrio sonoro natural. Observando-se a composição do encordoamento, vimos (exemplo musical 3) que os cinco pares de cordas não são todos organizados da mesma maneira, alguns estão em uníssono e outros oitavados. Essa diferença também é responsável por esse desequilibrio, pois os pares de cordas em uníssono ( 1 e 2) têm um som "menos encorpado" do que os pares oitavados (3, 4 e 5).

Além disso, em razão dos pares de cordas oitavados, a viola não tem o bordão (o som do baixo como o violão) e isto influi diretamente na montagem do acorde. A nota referente ao baixo do acorde é ouvida também uma oitava acima, o que, de certa forma, "embaralha" a noção de fundamental e também de inversão do acorde.

Tais características têm que ser observadas pelo intérprete e pelo arranjador. Se, em um arranjo, utilizarmo-nos da fórmula "melodia acompanhada com acordes" (na qual a melodia é tocada na "ponta", na voz mais aguda), a melodia estará sendo tocada principalmente nas cordas I e 2, justamente aquelas com amplitude menor $e$, o que seriam os baixos dos acordes de acompanhamento, serão tocados nas cordas graves $^{8}$ ( 4 e 5), aquelas com maior potência sonora.

A seguir, transcrevemos um pequeno trecho do arranjo de Carinhoso, no qual podemos observar a notação para a viola e, logo depois, o mesmo trecho com uma outra notação, onde foram incluídas as cordas oitavadas. $\bigcirc$ trabalho do intérprete é tentar traduzir o efeito do segundo trecho (notado com as cordas oitavadas) para o mais próximo possivel da notação do primeiro trecho. A melodia está na voz "da ponta", com hastes para cima.

8 Lembrar que essas cordas são oitavadas. 

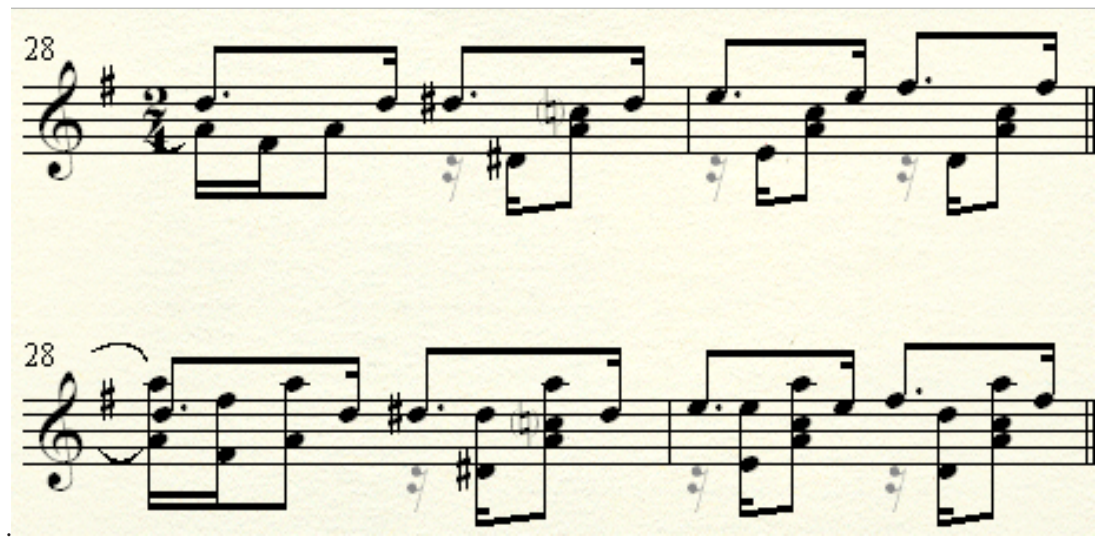

Exemplo musical 6. Notação normal e as cordas oitavadas.

Assim, o intérprete terá que equilibrar essa diferença natural que a viola apresenta utilizando-se de uma técnica apurada de mão direita no ataque das cordas.

\section{Do arranjo e sua interpretação}

Choro alimentou a vida cultural da cidade do Rio de Janeiro a partir do fim do século XIX (Tinhorão, 1974) e continua presente na cultura carioca. Ele surgiu no Rio de Janeiro, é um produto cultural da cidade e está fortemente associado a ela. Há uma enorme quantidade e variedade de obras produzidas dentro deste gênero musical'?

Sabemos que uma das principais características do Choro é a maneira de executar, que está também na essência do seu "nascimento", como descreveu Tinhorão: "O aparecimento do Choro, ainda não como gênero musical, mas como forma de tocar, pode ser situado por volta de 1870, e tem sua origem no estilo de interpretação que os músicos

9 Ao nos referirmos ao Choro, estaremos nos reportando tanto ao estilo interpretativo, quanto ao gênero musical. Não é nossa intenção discutir a relação entre gênero e estilo. Alguns pesquisadores abordaram este assunto em suas teses e dissertações, relacionando-o especificamente ao Choro e podemos sintetizá-lo da seguinte maneira: o estilo está relacionado à realização; e o gênero está relacionado mais à forma ou modelo estruturado. Mais informações podem ser encontradas nos trabalhos acadêmicos de Sá (1999), Salek (1999), Magalhães (2000), Verzoni (2000) e Carneiro (200 I).

\section{6}


populares do Rio de Janeiro imprimiam à execução das polcas [...]" (1974, p. 95).

Além do estilo interpretativo, outra característica do Choro está no atributo de que boa parte dos intérpretes eram também compositores e suas imagens ficaram associadas a determinados instrumentos. Assim, podemos relacionar facilmente alguns deles com seus respectivos instrumentos: Joaquim Callado e Patápio Silva (flauta), Pixinguinha (flauta e sax tenor), Chiquinha Conzaga e Ernesto Nazareth (piano), Luperce Miranda e Jacob do Bandolim (bandolim), João Pernambuco, Dilermando Reis e Garoto (violão), Luis Americano e Abel Ferreira (clarinete), Waldir Azevedo (cavaquinho), apenas citamos alguns.

Podemos, ainda, estabelecer uma relação entre o Choro e uma determinada formação instrumental, que ao longo dos anos consolidou-se como característica. Nos primórdios, com Callado, havia a base instrumental violão/cavaquinho tendo como instrumento solista, a flauta. A esse conjunto somaram-se o violão de 7 cordas, o bandolim e 0 pandeiro, formando a base instrumental do regional de Choro, que se manteve até a atualidade.

A viola é um instrumento harmônico que pode ser utilizado também como instrumento melódico $e$, neste caso, sua afinidade com a grande quantidade de Choros escritos para instrumentos melódicos como flauta, sax, clarinete ou bandolim ${ }^{10}$, é ime diata. Se nossa proposta não fosse a de um arranjo para uma execução solo (sem o acompanhamento de outros instrumentos), a partitura destas obras poderia ser lida diretamente na viola praticamente sem necessidade de adaptação.

\section{1 $O$ arranjo}

processo de realização do arranjo esteve permeado por certo grau de subjetividade, não só porque lidou com uma abordagem empírica, mas também porque estiveram envolvidas questões pessoais como gosto, criatividade, musicalidade, que influenciaram diretamente no seu desenvolvimento e também no resultado final.

10 Embora o bandolim seja também um instrumento harmônico, no Choro, ele tem como característica principal ser um instrumento solista, adquirindo caráter de instrumento melódico. Para um melhor entendimento deste assunto, consultar Ferrer (1996).

\section{7}


Termo "arranjo" está sendo adotado com o mesmo significado da definição encontrada no verbete do dicionário de música Grove"l, que reproduzimos a seguir:

A palavra 'arranjo' pode ser aplicada para qualquer peça de música baseada em ou que incorpore material pré-existente: a forma variação, o contracanto, a paródia, o pastiche, trabalhos litúrgicos baseados num cantus firmus, todos envolvem alguma parcela de arranjo. Na forma em que é normalmente usada entre músicos, entretanto, esta palavra pode ser adotada para significar tanto a transferência de uma composição de um meio para outro, quanto a elaboração (ou simplificação) de uma peça, com ou sem a mudança de meios. Neste caso, algum grau de recomposição está usualmente envolvido e o resultado pode variar de uma transcrição direta, quase literal, até uma paráfrase, que é mais o trabalho do arranjador do que do compositor original. (tradução livre) 12

Segundo esta definição, arranjo pode ser compreendido também como elaboração com algum grau de recomposição. $\bigcirc$ arranjo de Carinhoso mostrou níveis diferentes de alteração do material de origem (a partitura de referência). Ele foi pensado de forma descritiva, diferenciando-se da maioria das partituras de Choro, normalmente prescritivas $^{13}$, e está mais próximo a soluções musicais de cunho interpretativo. Discutiremos mais este assunto no item a seguir.

11 The new GROVE dictionary of Music and Musicians, 1980, p. 627.

12 Arrangement 1. Definition and scope. The word 'arrangement' might be applied to any piece of music based on or incorporating pre-existing material: variation form, the contrafactum, the parody mass, the pasticcio, and liturgical works based on a cantus firmus all involve some measure of arrangement. In the sense in which it is commonly used among musicians, however, the word may be taken to mean either the transference of a composition from one medium to another or the elaboration (or simplification) of a piece, with or without a change of medium. In either case some degree of recomposition is usually involved, and the result may vary from a straightforward, almost literal, transcription to a paraphrase which is more the work of the arranger than of the original composer.

13 Segundo Salek (1999) e Pires (1995), as partituras de Choro têm uma natureza prescritiva. Mesma opinião de Seve, que esclarece, "com relação às partituras [da música popular], pode-se dizer que 'o que se escreve nem sempre é o que se toca'. A notação muitas vezes corresponde apenas a um esboço ou proposta" (Sève, 1999, p. 11).

\section{8}




\subsection{Alguns procedimentos}

arranjo foi elaborado orientando-se pelo princípio da prática musical. Por meio dela procedemos criando e experimentando soluções musicais e selecionando aquelas que nos pareceram as melhores. Assim, estabeleceu-se um forte elo entre arranjo e interpretação.

Normalmente, há uma exigência maior nas obras feitas (compostas ou adaptadas ${ }^{14}$ ) para instrumentos melódicos do que em um arranjo a partir de uma partitura de violão ou piano. No primeiro caso, a notação apresenta-se com melodia e cifra, sendo composta por uma linha melódica solo que será tocada por um instrumento melódico (normalmente flauta, bandolim, clarinete etc) e com uma cifra indicando a harmonia, a ser tocada como acompanhamento por um ou mais instrumentos (normalmente violão, violão de 7 cordas, piano e/ou cavaquinho).

Para transformar esse conteúdo, objetivando a execução na viola solo, é necessário que se realize um trabalho de arranjo cuja principal tarefa é a junção da melodia com a harmonia (cifra). Nesse processo, estarão envolvidas tanto questões relativas ao instrumento, tais como definir a montagem dos acordes ou, ainda, elaborar um acompanhamento articulado para a cifragem em combinação com a melodia (sem perder de vista o caráter musical do Choro), quanto a questões relacionadas mais à estrutura da obra, como a liberdade para alterar ritmicamente a melodia ou para modificar a harmonia (inserindo dissonâncias ou mesmo mudando a harmonia original).

Neste caso, o arranjo passa a ser um trabalho que envolve a criação, no qual o arranjador deve ter um conhecimento consistente do instrumento e do gênero musical abordado. Durante a elaboração do arranjo, lançamos mão de nosso conhecimento e vivência no Choro e gêneros afins, como Polca, Maxixe e Samba, que fazem parte da tradição oral e que não podem ser apreendidos somente lidando com a partitura. É necessária uma "convivência" com estes gêneros por meio da prática in loco ou por meio da audição de CDs, DVDs e LPs ${ }^{15}$.

Além disso, nas partituras de Choro, de uma forma geral, não vêm indicadas a relação de dinâmica, o andamento, as articulações

I4 Utilizamos este termo como sinônimo de arranjo.

15 Outras possibilidades de registro e/ou reprodução (como por exemplo Internet e filmadoras) devem também ser utilizadas.

\section{9}


e os acentos na linha melódica; ou qualquer indicação sobre o tipo de acompanhamento e o tipo de acorde (região ${ }^{16}$ e organização interna), a percussão a ser utilizada, a condução de linha de baixo do violão de sete cordas com as inversões dos acordes e a liberdade de interpretação rítmica e melódica nas repetições. Assim, um arranjador que esteja familiarizado com tais peculiaridades tem a sua disposição "ferramentas" para poder realizar um arranjo com maior liberdade e segurança.

Para a execução, o intérprete deve seguir a mesma orientação. Apesar de o arranjo ter sido elaborado com soluções harmônicas, melódicas e rítmicas mais próximas de uma execução de fato, o intérprete deve buscar uma familiarização com o Choro. Há certas nuances que em geral são melhor assimiladas por transmissão oral.

\section{Análise}

A ideia para que a análise fosse elaborada sobre o arranjo e não sobre a partitura de referência originou-se na sugestão de Joel Lester, "Se as peças são consideradas como componentes de inúmeras possibilidades interpretativas, aparentemente aceitáveis, o foco da análise poderia, em vez de ser encontrar 'a' estrutura de uma peça, mudar para definir múltiplas estratégias para a interpretação das peças"17. Lester fala sobre diferentes propostas interpretativas para uma mesma obra (do repertório da música de concerto) adotadas por diferentes intérpretes e sugere que análises poderiam ser desenvolvidas a partir da interpretação, em contraponto às análises geralmente feitas a partir da partitura original composta pelo compositor. Esta proposta de Lester é uma sugestão que adotamos com duas adaptações: não apresentamos várias propostas de interpretação para uma única obra, mas sim uma proposta de arranjo para uma obra, já que estamos lidando com a criação de arranjo, que pode atuar em pontos estruturais e formais da obra, e não somente com interpretações ${ }^{18}$. Neste contexto,

16 No violão, um acorde pode ser feito em lugares diferentes no braço do instrumento, - que resulta em uma sonoridade mais brilhante ou mais escura, dependendo desta localização.

17 If pieces are regarded as composites of seemingly innumerable acceptable interpretative possibilities, the focus of analysis could shift from finding 'the' structure of a piece to defining multiple strategies for interpreting pieces. (In Rink, 1995, p. 214)

18 Segundo Lester (op.cit), o intérprete tem liberdade para atuar porém, dentro de certos limites impostos pela obra. 
o arranjo pode ser percebido também como estratégia pessoal para a interpretação da obra e a análise como a seleção e a exposição dessa estratégia.

Procedimento para a elaboração do arranjo, a partir da prática musical, com a seleção daquelas soluções musicais que nos pareceram melhores, estabeleceu um forte elo entre arranjo e interpretação. Ao analisarmos o arranjo estaremos, em certa medida, analisando as escolhas interpretativas criadas por nós.

Adotamos a definição de análise proposta por lan Bent:

Análise. A decomposição de uma estrutura musical em seus elementos constituintes relativamente mais simples, e a investigação da função desses elementos dentro dessa estrutura. Em tal processo, a "estrutura" pode ser parte de uma obra, uma obra na sua totalidade, um grupo ou até mesmo um repertório de obras, de tradição oral ou escrita. A distinção freqüentemente feita entre análise formal e análise estilistica é uma distinção pragmática, mas é desnecessária em termos teóricos. Ambas são abrangidas pela definição acima, pois, por um lado qualquer complexo musical, não importa quão grande ou pequeno, pode ser considerado um 'estilo', e por outro lado, todos os processos comparativos que caracterizam a análise estilística são inerentes à atividade analítica básica de reduzir a estrutura a seus elementos.

Uma definição mais geral do termo, como está implícito na linguagem comum, poderia ser: a parte do estudo da música que toma como ponto de partida a música em si, ao invés de fatores externos ${ }^{19}$ (Bent, 1987, p. 1).

19 Analysis. The resolution of a musical structure into relatively simpler constituent elements, and the investigation of the function of those elements within that structure. In such a process the 'structure' may be part of a work, a work in its entirely, a group or even a repertory of works, in a written or oral tradiction. The distinction often drawn between formal analysis and stylistic analysis is a pragmatic one, but is unnecessary in theoretical terms. Both fall within the above definition, since on the one hand any musical complex, no matter how small or large, may be deemed a 'style'; and on the other hand, all the comparative processes that characterize stylistic analysis are inherent in the basic analytical activity of revolving structure into elements.

A more general definition of the term as implied in common parlance might be: that part of the study of music which takes as its starting-point the music itself, rather than external factors. (Bent, 1987, p. 1).

\section{1}

REV. TULHA, RIBEIRÃO PRETO, v. 2, n. 2, p. 94-153, jul.-dez. 2016 
Segundo Bent, análise pode ser entendida como a identificação dos elementos constituintes da estrutura musical e a investigação da função desses elementos dentro dessa estrutura. No nosso caso, a estrutura musical a ser analisada constitui-se no arranjo para a viola solo; e a identificação dos elementos constituintes junto à investigação de suas funções representa exatamente o trabalho desenvolvido neste artigo.

Bent finaliza sua definição com a observação de que o ponto de partida para a análise deve ser a própria música. Na elaboração da análise aqui exposta, os critérios que orientaram o seu desenvolvimento foram definidos a partir do próprio arranjo, ao procurarmos identificar aqueles elementos estruturais que se diferenciavam das estruturas encontradas na partitura de referência.

Assim, adotamos a análise comparativa como linha condutora geral porque possibilita a confrontação entre a obra e o arranjo. Por meio dela, o trabalho realizado no arranjo pode ser destacado de forma clara e objetiva.

\subsection{Carinhoso}

"O Carinhoso foi composto por volta de 1916 e 1917. Quando eu fiz o Carinhoso, era uma polca. Polca lenta. Naquele tempo, tudo era polca, qualquer que fosse o andamento. Tinha polca lenta, polca ligeira, etc. $\bigcirc$ andamento do Carinhoso era o mesmo de hoje e eu o classifiquei de polca lenta ou polca vagarosa." Depoimento de Pixinguinha (apud Silva, 1979, p. 160).

Carinhoso é uma das composições mais conhecidas de Pixinguinha. Em 1928, ela foi gravada pela "Orquestra Típica Pixinguinha-Donga", com arranjo do próprio autor. Originalmente instrumental, em 1937 recebeu letra de João de Barro e foi cantada pela primeira vez em público pela atriz Heloisa Helena, sendo gravada no ano seguinte por Orlando Silva. Carinhoso foi classificada pelo próprio Pixinguinha como uma "Polca lenta", mas posteriormente outros músicos e pesquisadores 
consideraram diferentes possibilidades de classificação como Choro20, Choro-canção2l e Samba-canção22.

A versão que tomamos como "partitura de referência" para o trabalho de arranjo não é o manuscrito de 1917, mas a edição de 1997, da Irmãos Vitale, com revisão melódica de Antônio Carrasqueira e com uma harmonização mais moderna, assinada por Edmilson Capelupi ${ }^{23}$. Esta edição tem os direitos pertencentes à editora Mangione.

que apresentamos a seguir é uma análise comparativa entre a partitura de referência e o arranjo ${ }^{24}$ feito para a viola solo, na qual destacamos uma série de elementos contidos no arranjo. Definimos cinco tópicos para o desenvolvimento da análise deste arranjo:

1) Melodia;

l. 1) Transposição;

1.2) Variações rítmicas;

1.3) Variações melódicas;

1.4) Dobramentos;

1.5) Contração;

1.6) Ornamentos;

2) Harmonia;

3) Referências extra-partitura;

4) Forma; e

5) Técnica.

20 Alencar, 1979, p. 59.

21 Carrasqueira, 1997, p. 28. Coordenado por Maria José Carrasqueira. Copyright () 1936 by MANCIONE, FILHOS \& CIA LTDA. Todos os direitos autorais reservados para todos os países do mundo.

22 Marilia T. Barbosa da Silva e Arthur L. de Oliveira filho, os autores, afirmam que Pixinguinha "havia composto, mais de dez anos antes, o primeiro samba-canção, sem ter consciência de haver criado um novo gênero"(Silva \& Oliveira Filho, 1979, p. 160).

23 Anexo 1.

24 Anexo 2.

\section{3}


Os exemplos comparativos apresentam sempre o seguinte esquema: primeiro, o trecho na partitura de referência $e$, logo a seguir, o mesmo trecho no arranjo. As diferenças entre ambos vêm destacadas por retângulos. As exceções a esse esquema são os exemplos do item 1.6 (Ornamentos) e aqueles exemplos em que falamos da coda.

A partir do compasso 24, os exemplos mostrarão uma diferença na contagem dos compassos entre a partitura de referência e 0 arranjo, porém o trecho musical entre ambos será o mesmo. $\bigcirc$ motivo dessa defasagem está explicado no item 1.5 (Contração).

1) Melodia

1.1) Transposição.

Sob este título, encontram-se dois enfoques. Primeiro, a transposição de toda a obra, da tonalidade original para uma outra tonalidade que proporcionasse à viola um efeito sonoro melhor. Dessa forma, "Carinhoso" foi transposta da tonalidade original (Fá maior) para a tonalidade uma segunda maior acima (Sol maior). $\bigcirc$ arranjo foi trabaIhado com base na transposição para Sol maior por proporcionar, de antemão, uma afinidade com a viola afinada em Rio abaixo.

O segundo enfoque relaciona-se com uma característica de interpretação do Choro. Quando executado por flautistas, a transposição de trechos da melodia, para uma oitava acima, é bastante comum, obtendo-se mais brilho e volume. No arranjo, fizemos uso dessa característica de interpretação em dois pequenos trechos, transpondo-os não uma oitava acima, mas uma oitava abaixo.

No exemplo musical 7, o início da introdução foi transposto uma oitava abaixo.

\section{4}




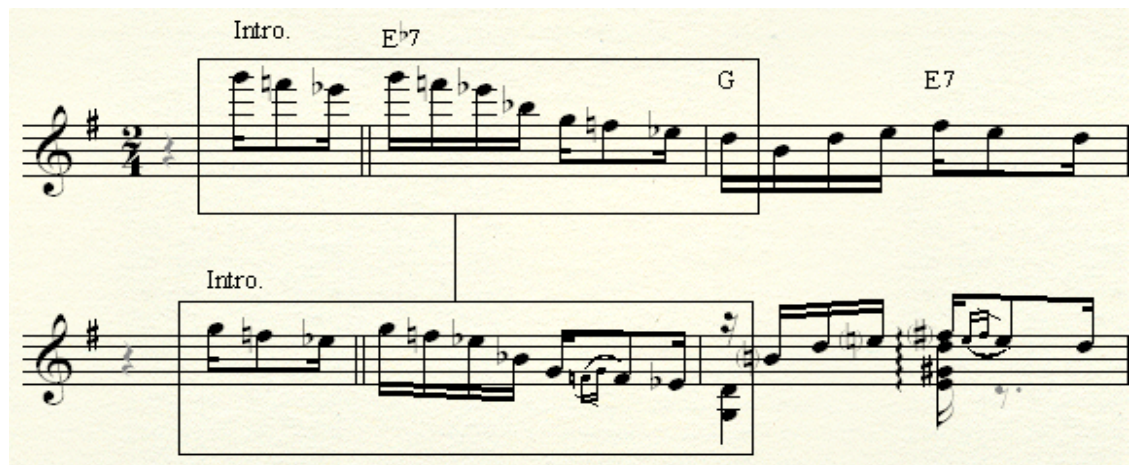

Exemplo musical 7. Transposição.

Oexemplo musical 8 mostra, no arranjo, um pequeno trecho transposto oitava abaixo e com uma variação rítmica ${ }^{25}$

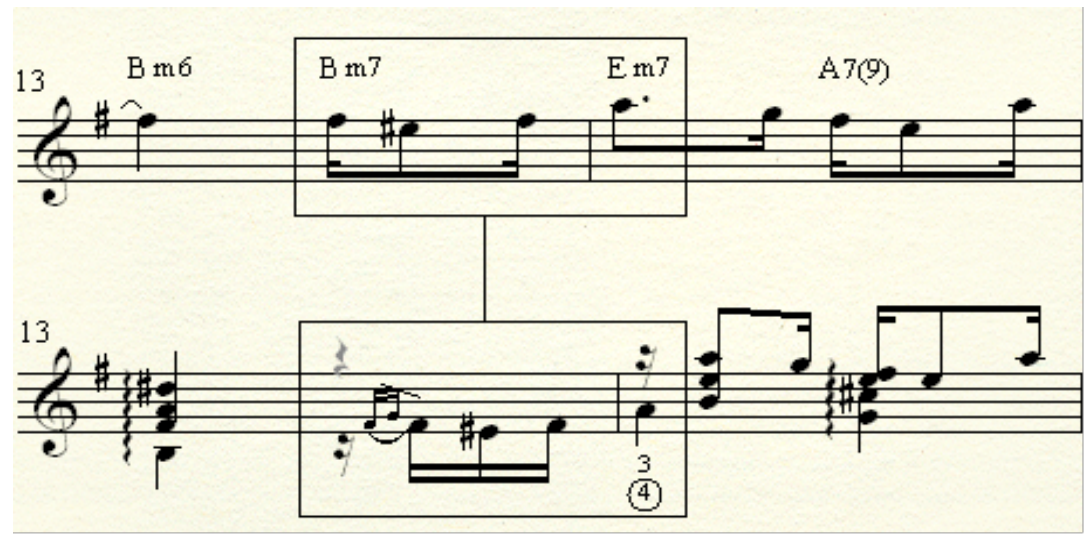

Exemplo musical 8. Transposição.

1.2) Variações rítmicas

Uma parcela significativa das mudanças rítmicas que implementamos na melodia foi decorrente da necessidade de adaptação para a execução em um só instrumento ${ }^{26}$. Ou seja, para que pudéssemos

25 As variações rítmicas da melodia serão comentadas no item 1.2 Variações rítmicas.

26 Abordamos essa questão no capítulo 3, item 3.2.1 Alguns procedimentos. 
interpretar na viola, harmonia e melodia juntas, foram adotadas pequenas variações rítmicas da melodia. Os próximos seis exemplos musicais $(9,10,11,12,13$ e 14) ilustram esse procedimento.

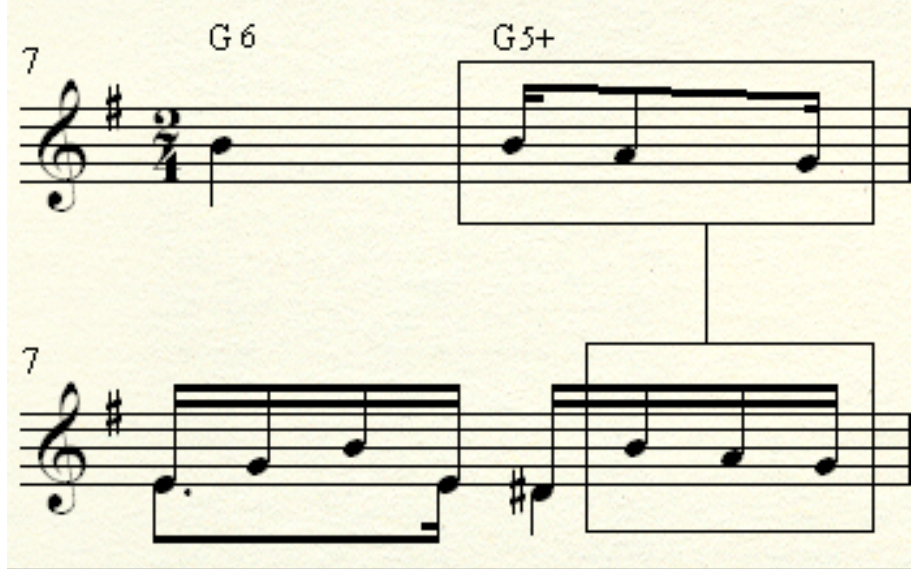

Exemplo musical 9. Mudança rítmica da melodia.

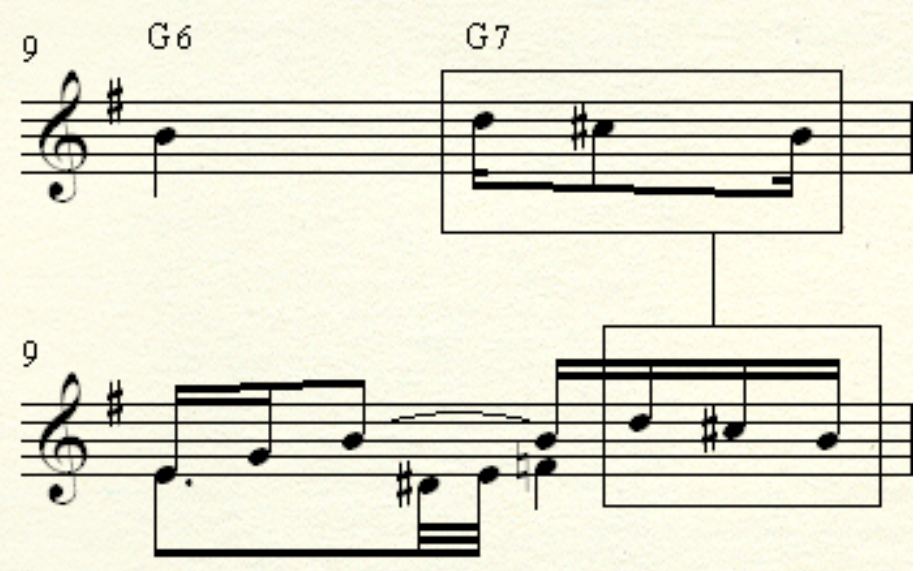

Exemplo musical 10. Mudança rítmica da melodia. 


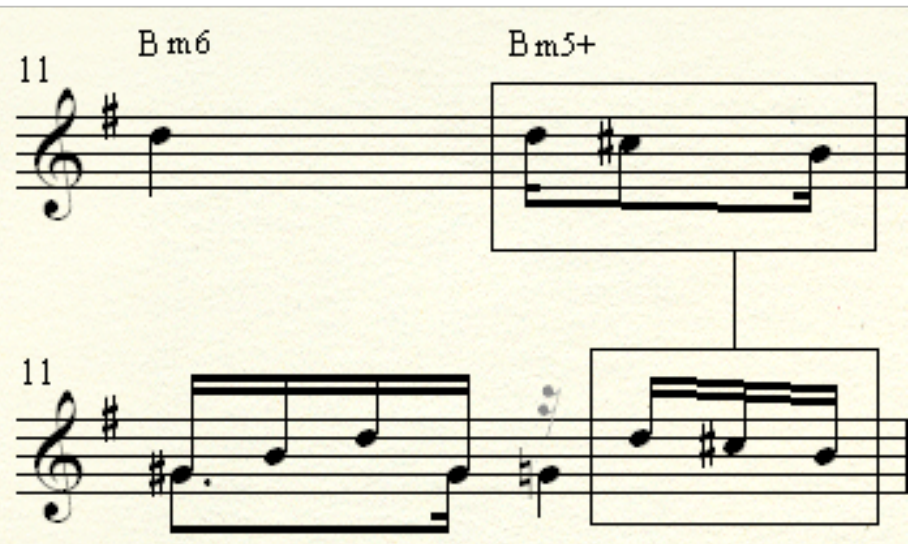

Exemplo musical I1. Mudança rítmica da melodia.

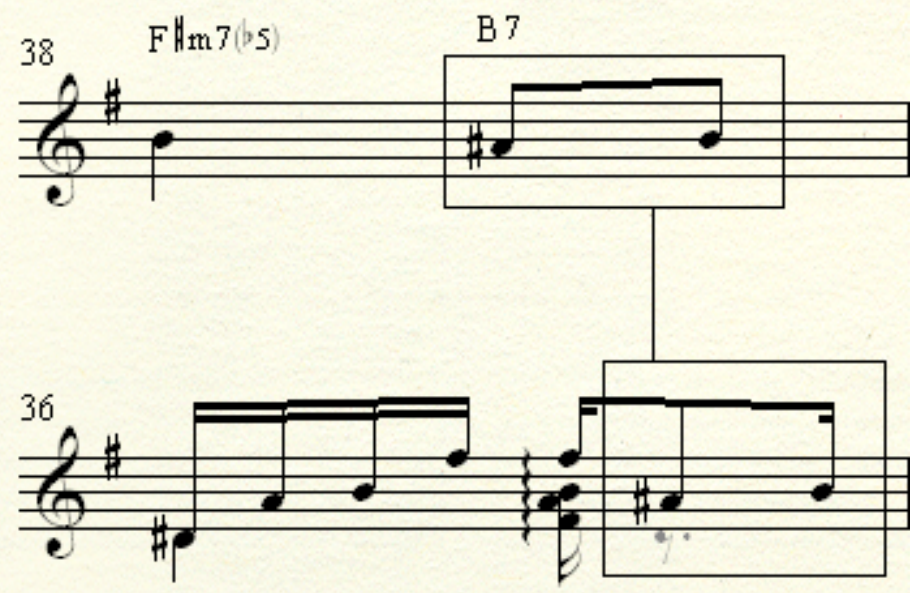

Exemplo musical 12. Mudança rítmica da melodia. 


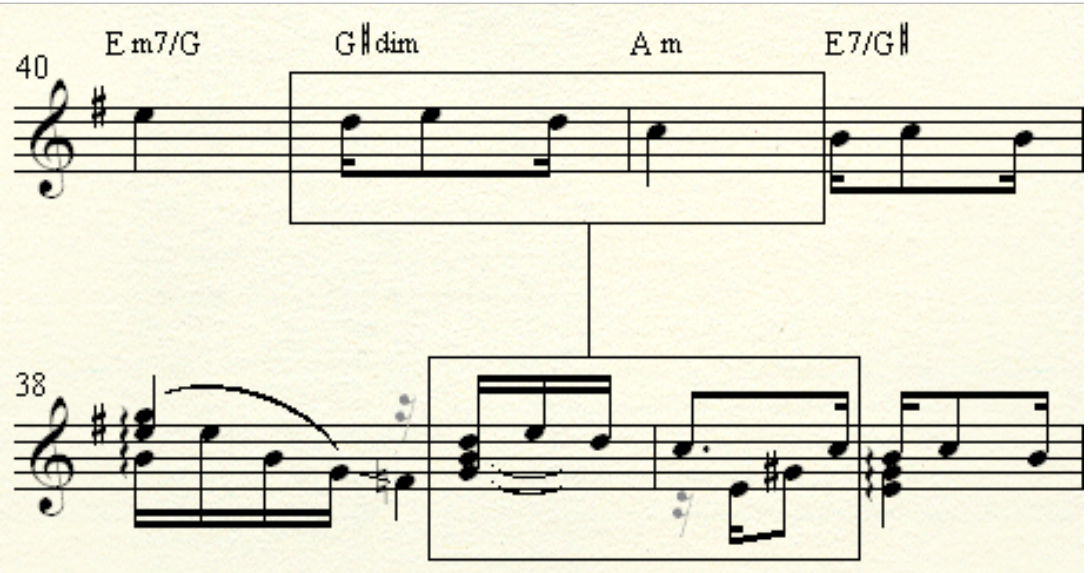

Exemplo musical 13. Mudança rítmica da melodia.

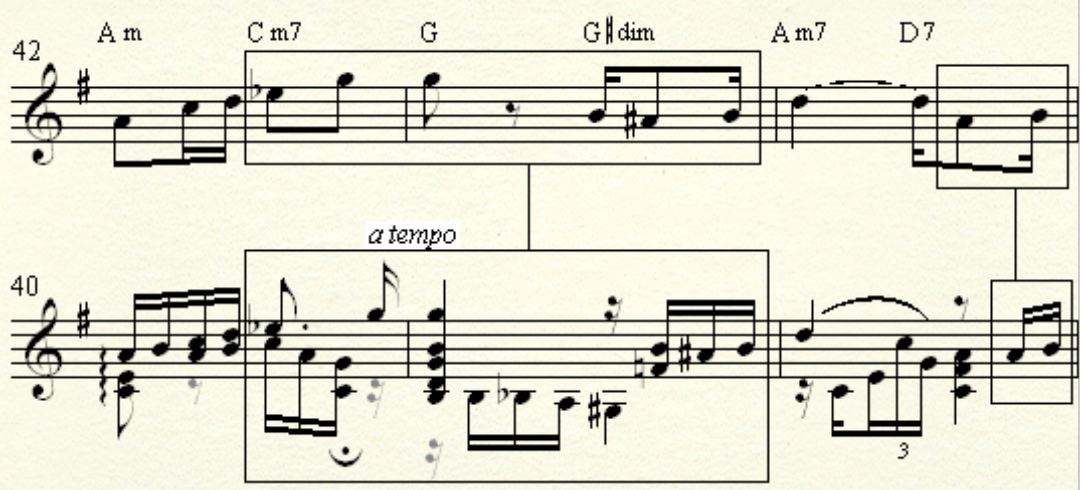

Exemplo musical |4. Mudança rítmica da melodia.

Uma outra parcela de mudanças rítmicas na melodia é de caráter interpretativo. Os quatro exemplos musicais a seguir $(15,16,17$ e 18) ilustram também esse procedimento. 


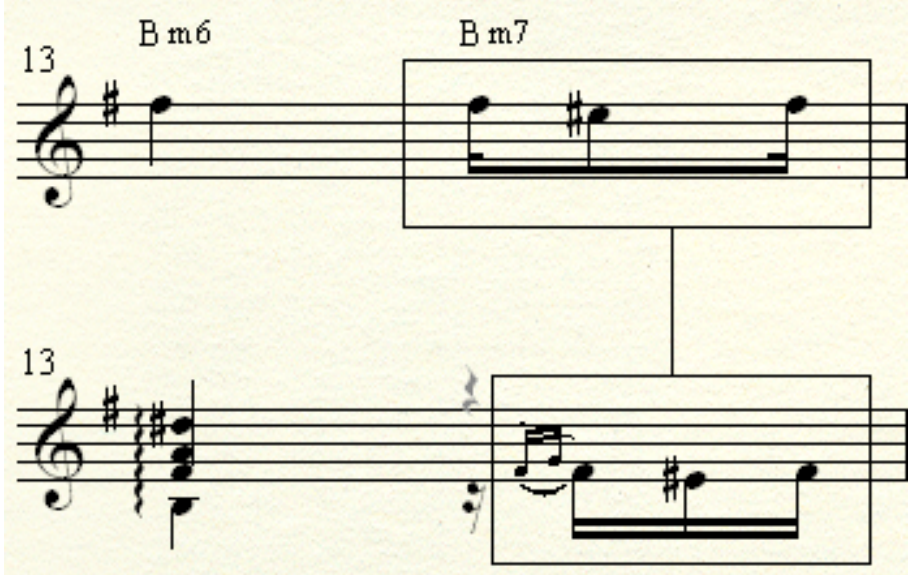

Exemplo musical 15. Mudança rítmica da melodia.

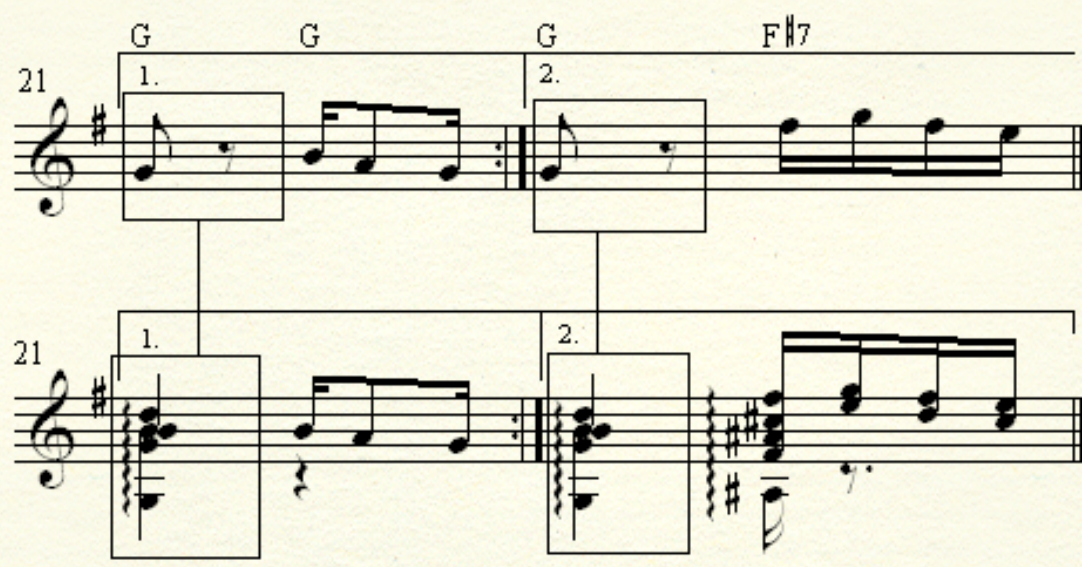

Exemplo musical 16. Mudança rítmica da melodia. 


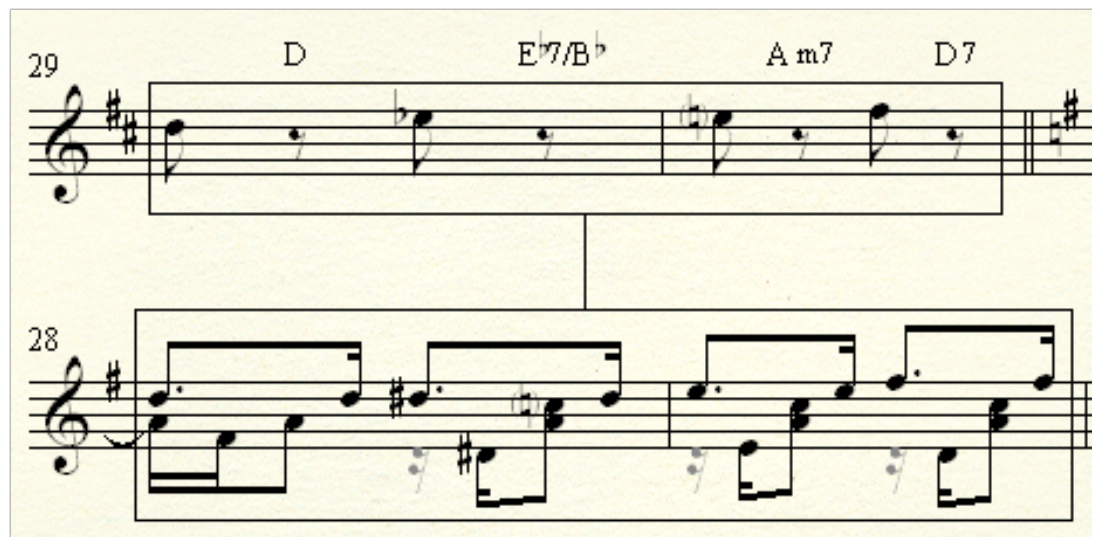

Exemplo musical 17. Mudança rítmica da melodia.

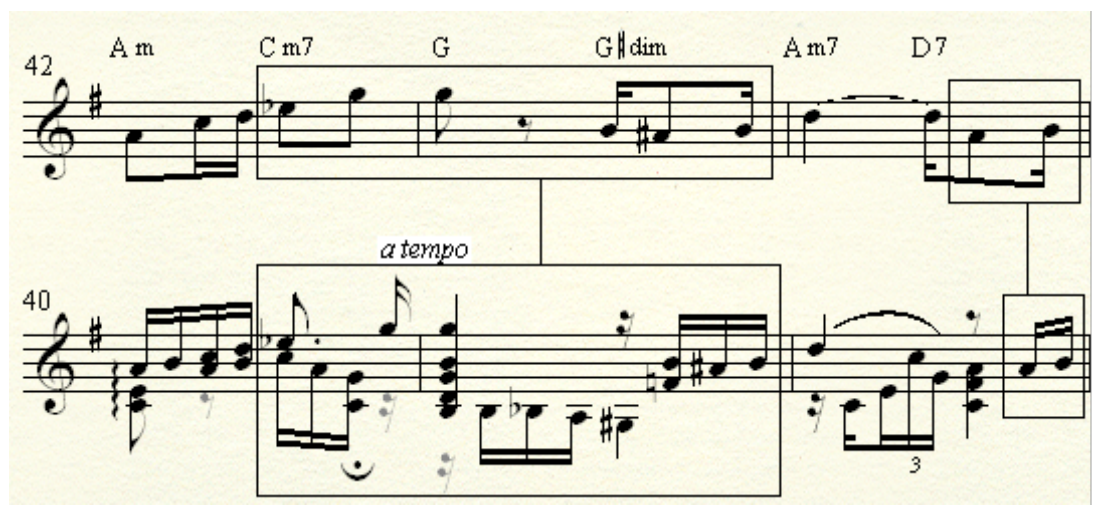

Exemplo musical 18. Mudança rítmica da melodia.

No exemplo musical 19, apresentamos o resumo, em forma de esquema, de todas as variações rítmicas que foram adotadas ao longo do arranjo. 


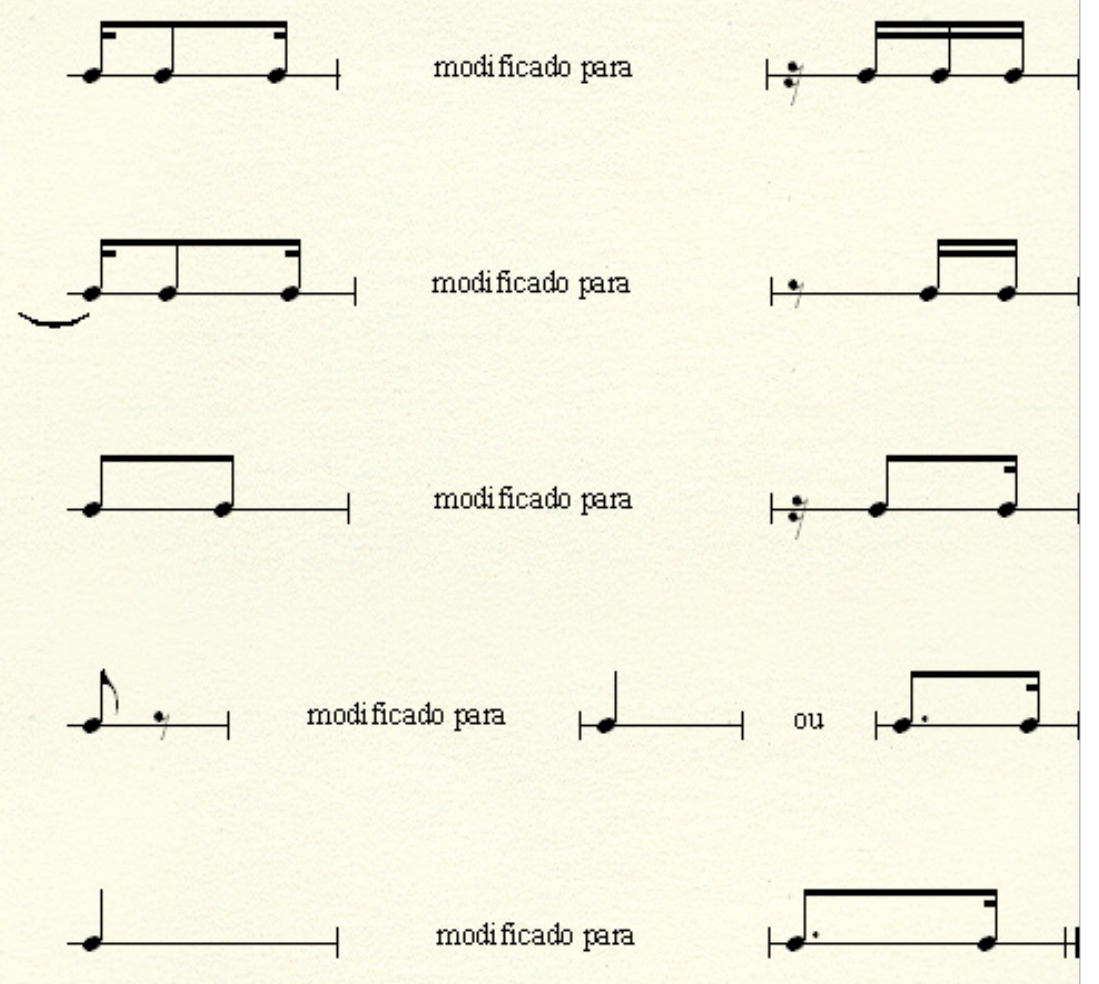

Exemplo musical 19. Esquema das mudanças rítmicas da melodia.

1.3) Alteração da linha melódica.

O contorno melódico no arranjo foi mantido fiel ao original em praticamente toda a sua extensão. Há apenas duas alterações.

O exemplo musical 20 mostra a melodia original no primeiro pentagrama, destacada no retângulo, tocando as notas si3-dó4-si3-fá sustenido3 e, no pentagrama abaixo, a alteração melódica implementada no arranjo. A nota "dó 4" foi substituída pela nota "lá3" e a nota "fá sustenido3" foi substituída por uma linha melódica em terças que acaba nas notas "re4-fá sustenido4". 


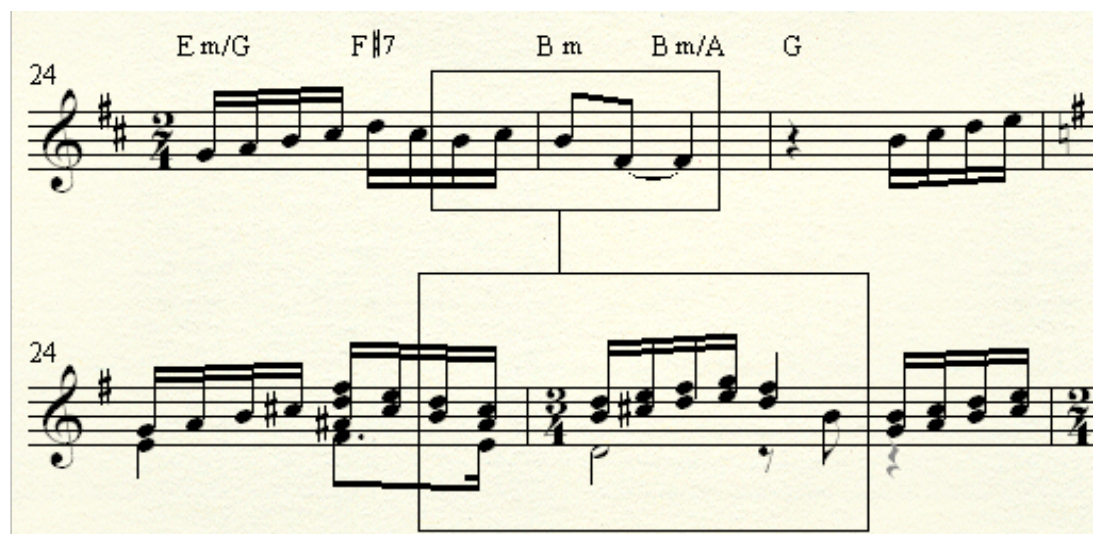

Exemplo musica 20. Alterações na melodia original.

A segunda alteração do contorno melódico está ilustrada no exemplo musical 21. Pode-se observar que a nota re5 (2 tempo) foi suprimida ${ }^{27}$.

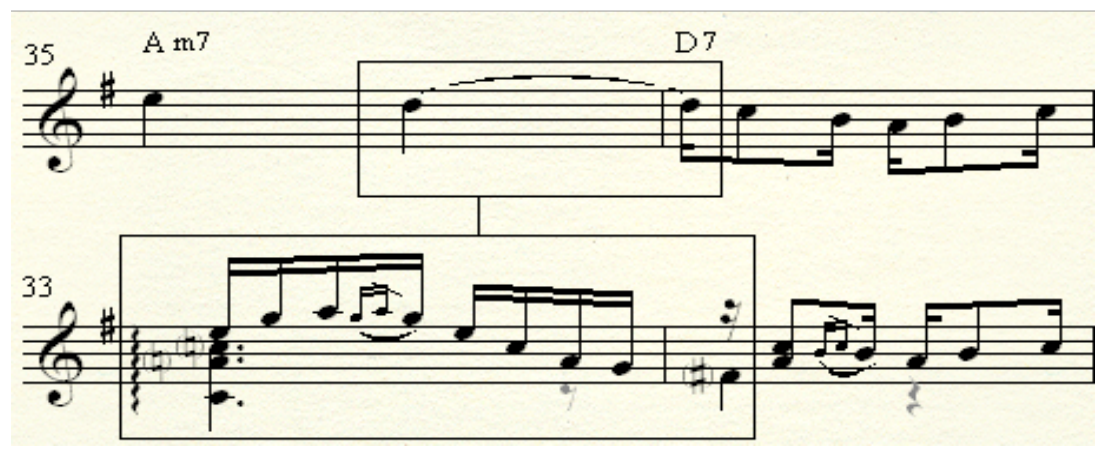

Exemplo musical 21. Alterações na melodia original.

\section{4) Dobramentos de $3^{a}$ e $6^{a}$.}

Uma liberdade que tomamos, foi a utilização de dobramentos em intervalos de terças e sextas, tanto na melodia, quanto nos contracantos. Com isso, introduzimos uma familiaridade sonora tradicional e característica do instrumento, aproximando o universo da viola sertaneja com o Choro.

27 Falaremos sobre essa questão no item 3) Referências extra-partitura. 
Os próximos seis exemplos musicais, 22, 23, 24, 25, 26 e 27, evidenciam os trechos onde utilizamos o dobramento em terças:

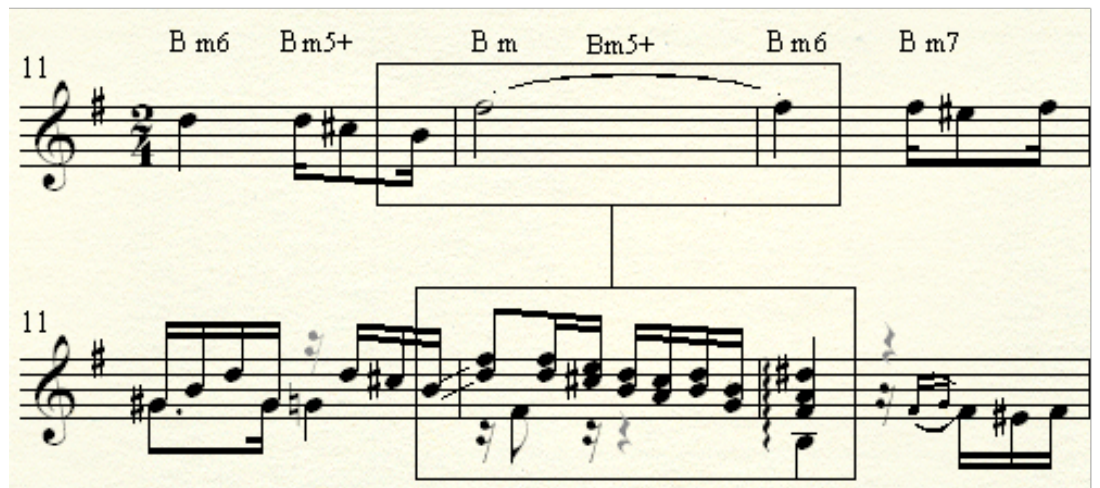

Exemplo musical 22. Dobramento de terça.

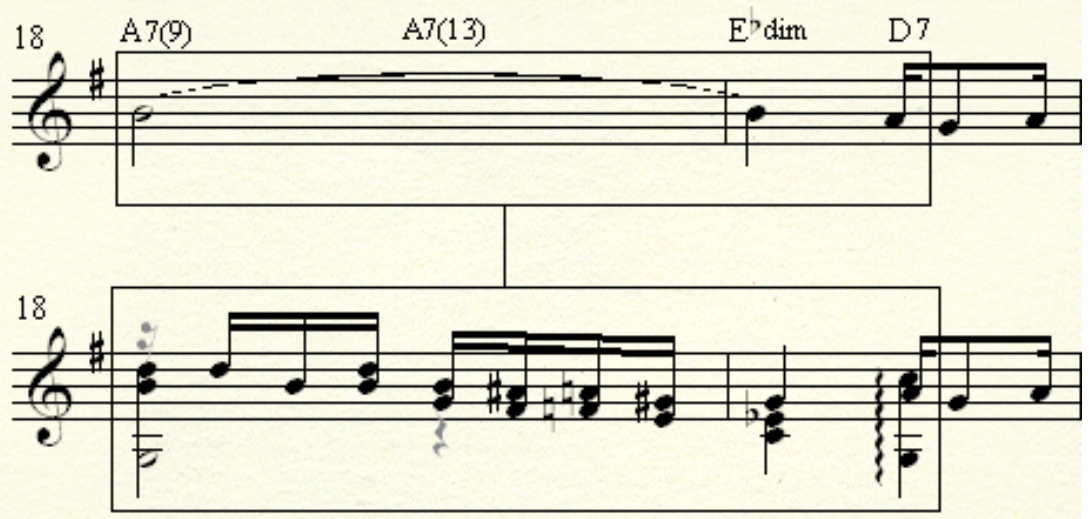

Exemplo musical 23. Dobramento de terça.
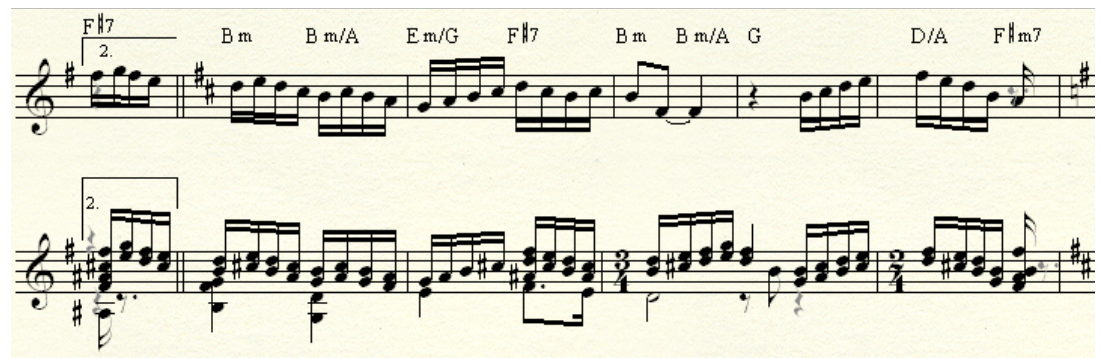

Exemplo musical 24. Dobramento de terça. 


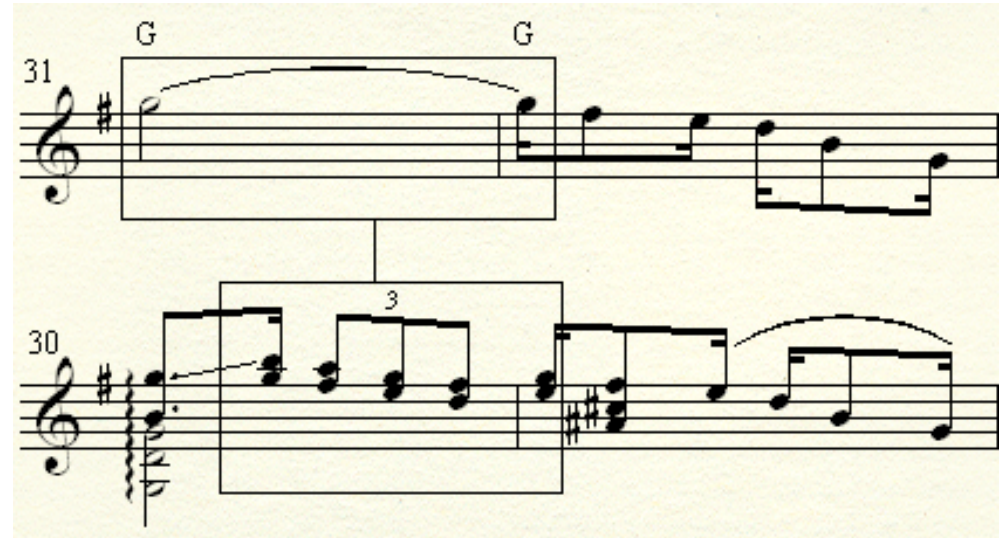

Exemplo musical 25. Dobramento de terça.

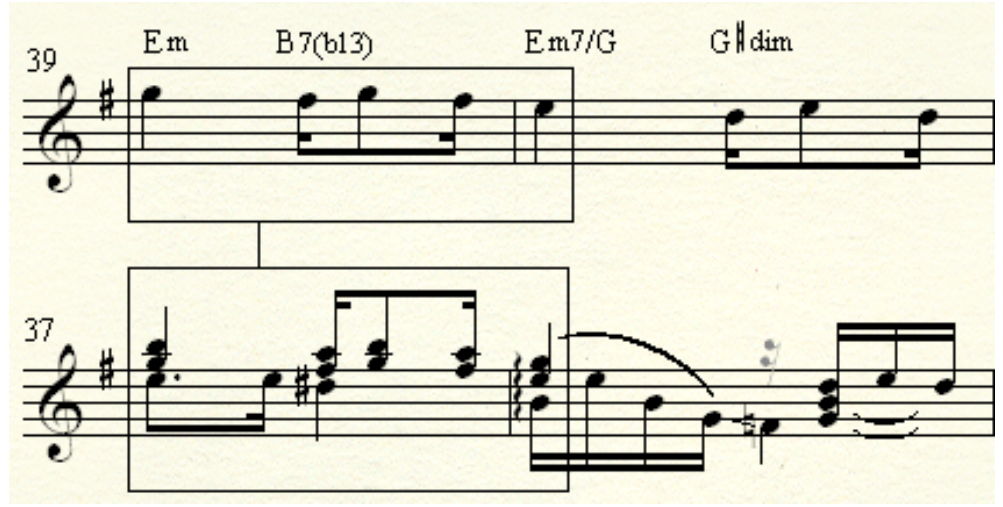

Exemplo musical 26. Dobramento de terça. 


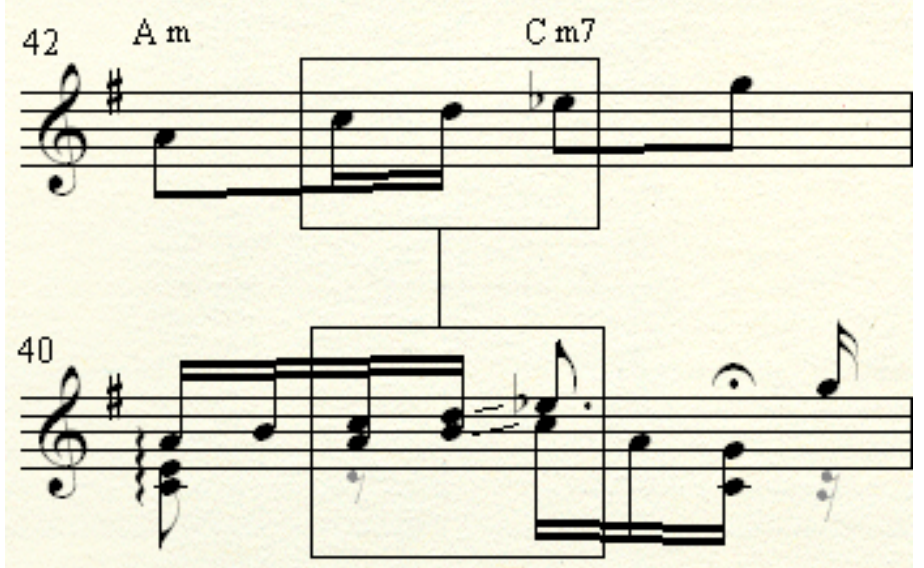

Exemplo musical 27. Dobramento de terça.

No exemplo musical 28, mostramos o trecho melódico onde ocorreu o dobramento em sextas.

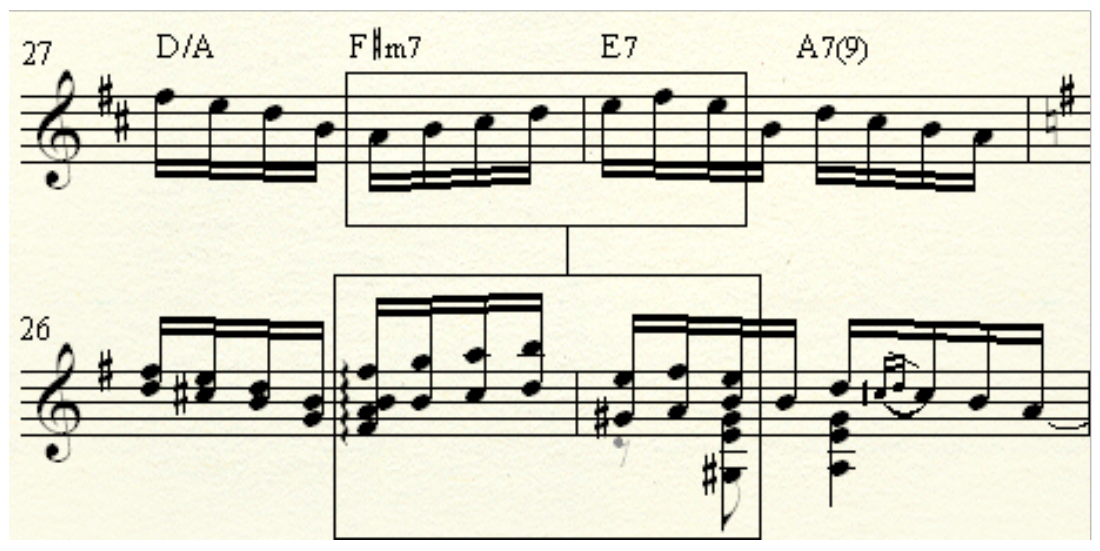

Exemplo musical 28. Dobramento de sexta.

\section{5) Contração}

Já comentamos anteriormente que o arranjador e o intérprete podem se permitir uma série de liberdades e o presente item é uma consequência dela. Os próximos dois exemplos musicais (29 e 30) mostram formas de contração melódica que resultaram também em "contração de compassos". 
No exemplo musical 29, os compassos 25 e 26, da partitura de referência, foram contraídos para um compasso de $\square$, no arranjo (o compasso 25). Essa contração ocorreu pela eliminação da pausa, no $1{ }^{\circ}$ tempo do compasso 26.

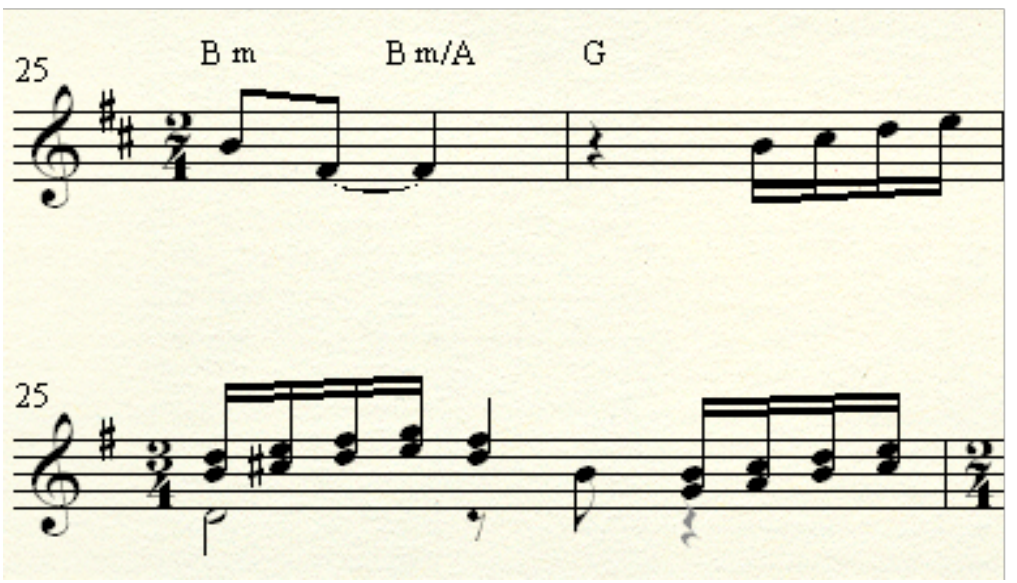

Exemplo musical 29. Contração melódica.

No exemplo musical 30, a melodia foi contraída por diminuição da figura rítmica. Os compassos 33 e 34, da partitura de referência, foram contraídos para um compasso de 2/4, o compasso 32.
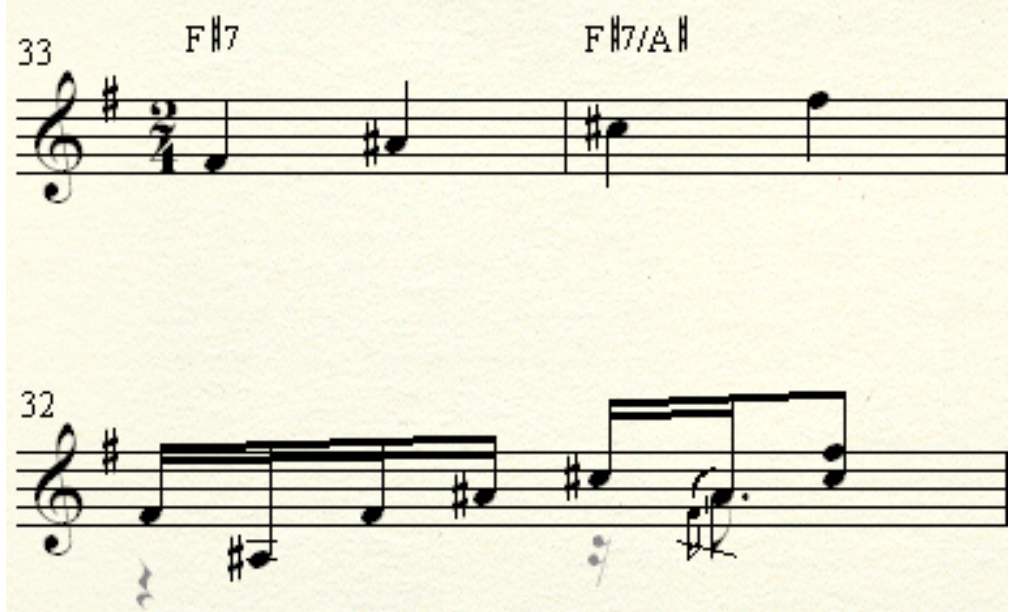

Exemplo musical 30. Contração melódica. 
Pela observação dos dois exemplos, percebe-se que a contração alterou a contagem dos compassos, resultando em uma diferença entre eles. Até o compasso 25, ambos pentagramas apresentam a mesma contagem para o mesmo trecho musical, mas, a partir daí, há uma defasagem de um compasso e, a partir do compasso 33, a defasagem se amplia para dois compassos de diferença sobre o mesmo trecho musical.

\section{6) Ornamentos.}

No Choro, normalmente os ornamentos não são notados. Podemos dizer que eles se enquadram na esfera de atuação do intérprete e que são bastante utilizados de uma forma livre. Apesar disto, escrevemos alguns ornamentos no arranjo procurando dar uma roupagem mais próxima de uma interpretação real. Os ornamentos que utilizamos foram: Apogiaturas (inferiores) - apog. / Bordaduras (superiores) - bord. / Portamentos - port. / Clissandos - gliss.
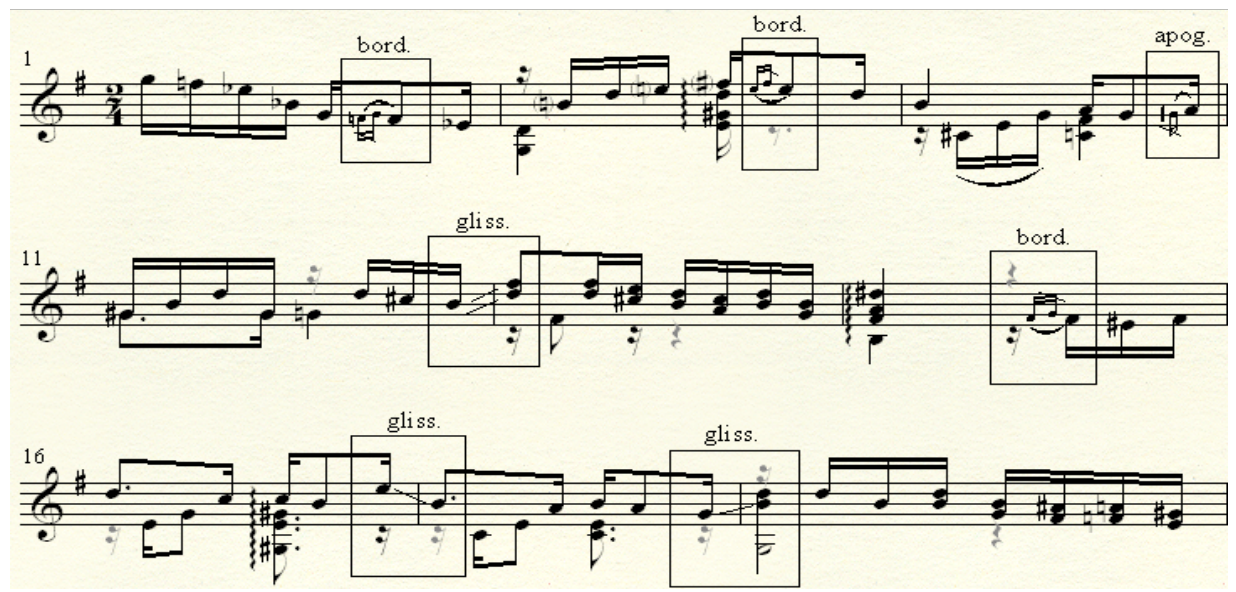

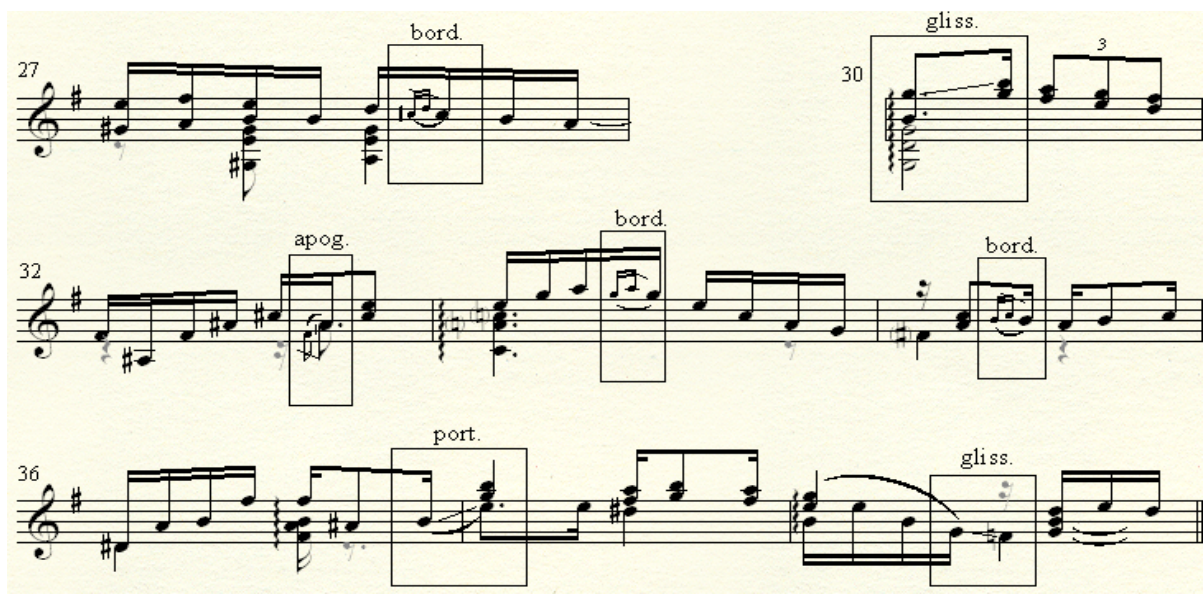

Exemplo musical 31 . Ornamentos.

\section{2) Harmonia}

Já mencionamos que a partitura que nos serviu de base para o arranjo foi uma versão de 1997, editada pela Irmãos Vitale, com uma harmonização mais moderna de Edmilson Capelupi. À época em que Pixinguinha compôs este Choro, a harmonia utilizada era formada por acordes triádicos - maior, maior com quinta aumentada, menor e diminuto - e pelo tetracorde dominante (com a sétima menor). "Carinhoso" foi composta dentro da chamada harmonia tonal funcional e a versão de 1997 manteve esta característica.

A possibilidade de realizar mudanças na harmonia original é uma opção que faz parte do métier do arranjador e nos utilizamos dessa importante ferramenta no arranjo. De uma forma geral, tanto a categoria do acorde ${ }^{28}$, quanto a função harmônica ${ }^{29}$, foram mantidas. Organizamos a exposição dos exemplos pela ordem de aparição no arranjo. Eles vêm acompanhados dos respectivos comentários. No fim deste item 2, apresentaremos um quadro com um resumo contendo todas as mudanças.

28 Segundo Chediak (1984, p. 30), as categorias são quatro: maior, menor, $7^{0}$ da dominante $e 7^{0}$ diminuta.

29 As funções harmônicas são três: Tônica (I, III e VI); Subdominante (IV e II) e Dominante $(\mathrm{V} e \mathrm{VII})$. 
exemplo musical 32 mostra três acordes destacados por re-

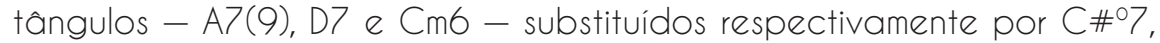
$\mathrm{F} \# \mathrm{~m}(\mathrm{~b} 5)$ e $\mathrm{Am} 7(\mathrm{~b} 5) / \mathrm{C}$. Os dois primeiros são acordes dominantes $V$ que foram substituídos pelos respectivos acordes do VII. $\bigcirc$ terceiro acorde, Cm6, é o IV do tom homônimo menor. Este acorde é a primeira inversão do acorde que utilizamos no arranjo - Am7(b5).
$A 7(9)$
substituído por $\mathrm{C} \#$ 07
V7N
$\vee \|^{\circ} 7 \mathrm{~N}$
D7
substituido por $\mathrm{F} \# / \mathrm{C}$
V7
VIIm(b5)
Cm6 substituído por $A m 7(b 5) / C$
IVm6 (a.e.m.) ${ }^{30}$
$\| m 7$ (b5) (a.e.m.)

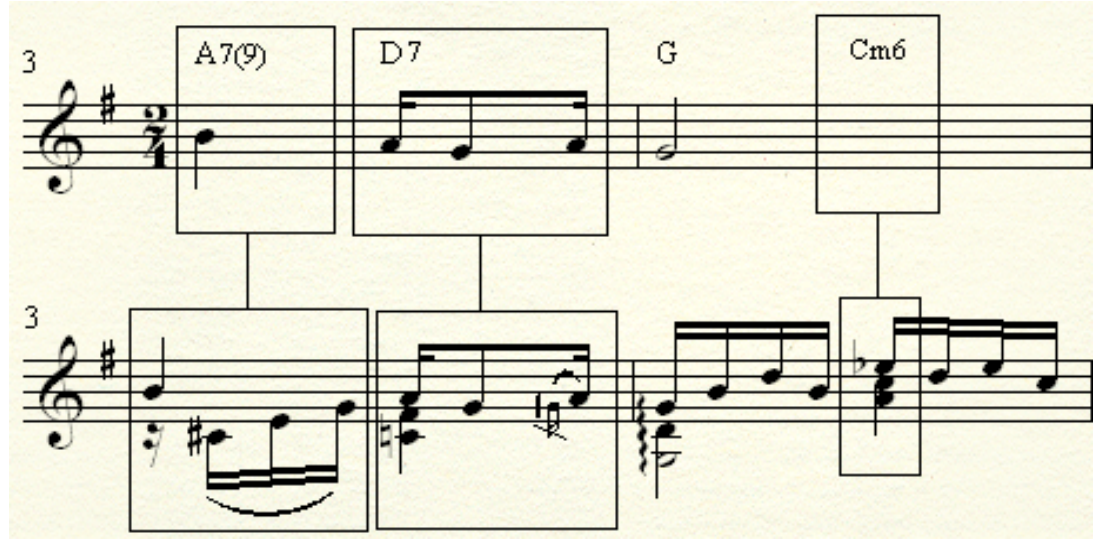

Exemplo musical 32. Mudanças na harmonia.

Exemplo musical 33. Utilização do pedal da nota sol, no acorde de Bm.

$\mathrm{Bm}$ substituido por Bm/C IIIm $\underline{\| \mathrm{Im}(1)}$

30 Acordes de empréstimo modal, são acordes emprestados da tonalidade homônima menor. 


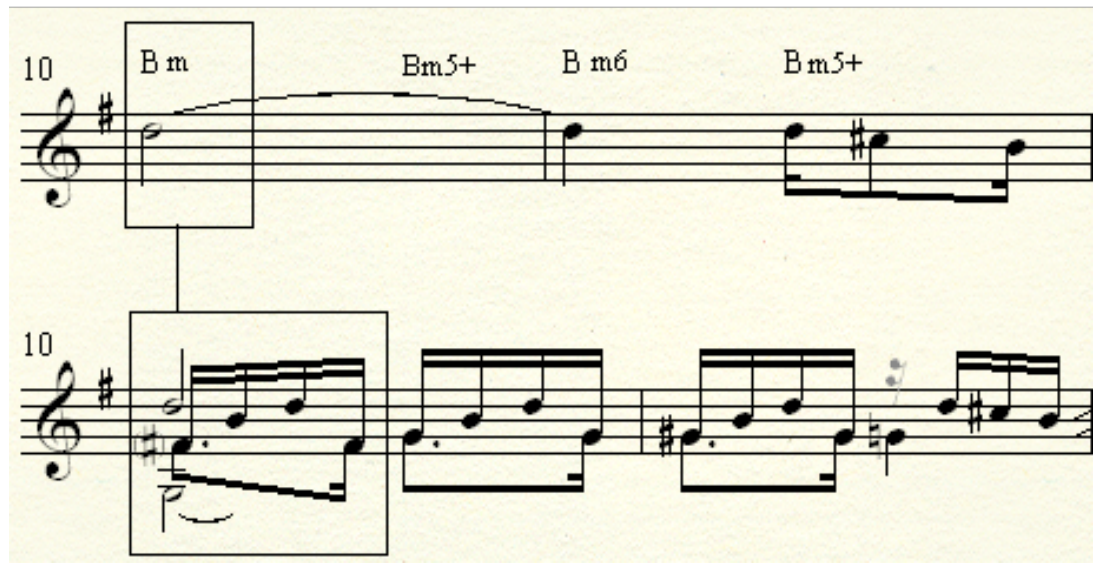

Exemplo musical 33. Mudanças na harmonia

No exemplo musical 34, o acorde dominante B7, substitui o acorde de Bm6.
Bm6
substituído por B7
|llm6
$\vee 7 N \mid m$

Esta mudança de harmonia ocasionou, também, a mudança da função harmônica. $\bigcirc$ acorde de Bmb tem função tônica de III e o seu substituto é um acorde de B7, de função dominante, ainda que momentaneamente ${ }^{31}$.

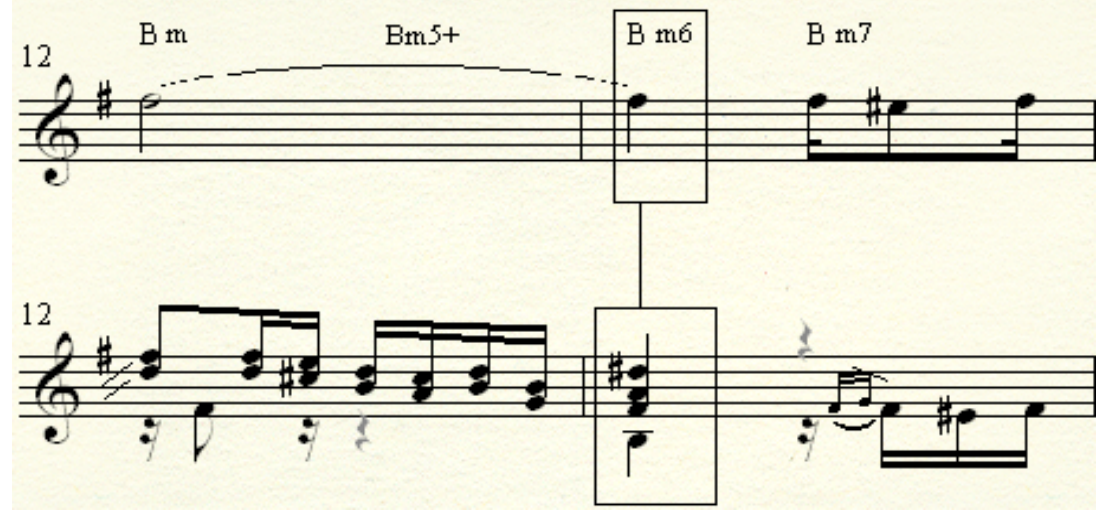

Exemplo musical 34. Mudanças na harmonia.

31 Sobre esta questão nos baseamos em Piston (1969, p. 165-177) "Secondary dominants". 
Exemplo musical 35. Acorde de E/C\# substitui o acorde de B.

acorde diminuto $B^{\circ}$ é um acorde dominante que conduz a harmonia para Am7. Ele foi analisado aqui como uma inversão do acorde $\mathrm{C} \#^{\circ}$, VII de Am. A substituição pelo acorde E/C\# seguiu esta interpretação, mantendo o caráter dominante do acorde - VII/Im pelo V/IIm.

$B^{\circ}$ substituido por E/C\#

$\mathrm{V}\|\mathrm{O} /\| \mathrm{m}$

$\mathrm{V} / \| \mathrm{m}$

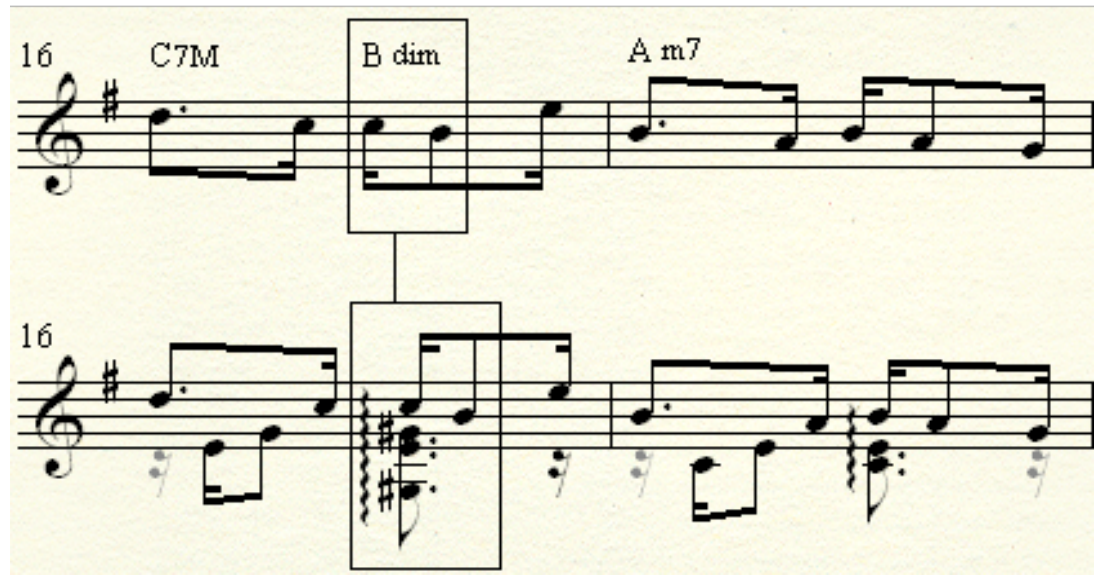

Exemplo musical 35. Mudanças na harmonia

exemplo musical 36 mostra duas mudanças harmônicas. $\mathrm{Na}$ primeira, o acorde dominante $A 7(9)$ foi substituido pelo acorde de $\mathrm{C}$, de função tônica. Comp. 18 - acorde de $G$ no lugar de A7(9). Na segunda mudança, o acorde dominante Eb $b^{\circ}$ foi substituído pelo acorde $\mathrm{Cm}$, subdominante do homônimo menor.
$A 7(9)$
substituído por $\mathrm{C}$
VN
$E b^{0} 7$
substituído por $\mathrm{Cm}$
$b \mid 1107$
$\mathrm{IVm}$ (a.e.m.) 


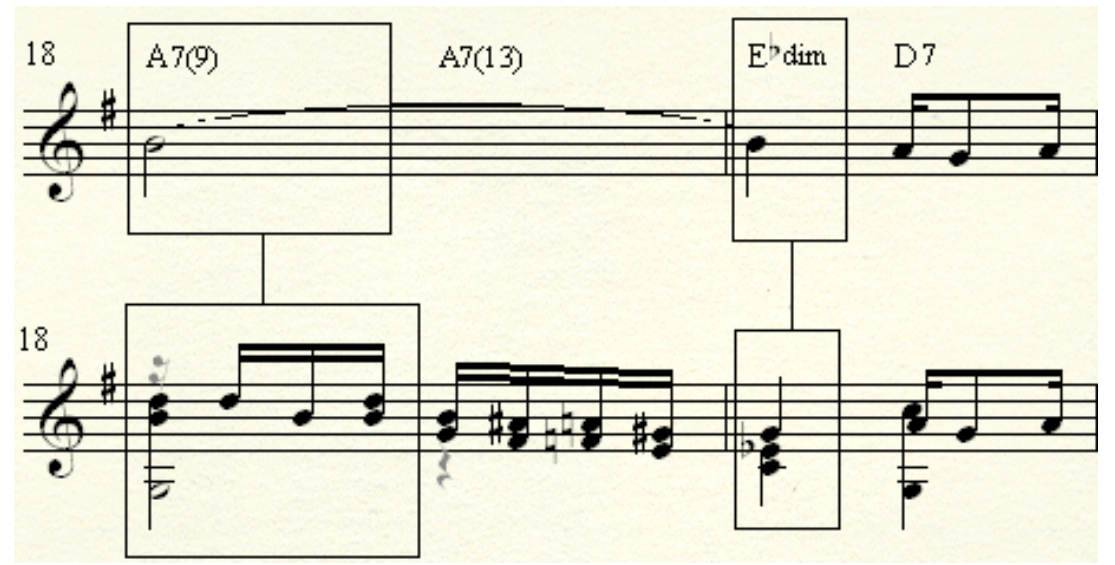

Exemplo musical 36. Mudanças na harmonia.

Exemplo musical 37. Acorde de G(4,9) substituindo o acorde dominante D732.

$$
\begin{array}{r}
\text { D7 substituído por } C(4,9)-D 7 / C \\
\text { V7 } \quad-\underline{v 7 / 1}
\end{array}
$$

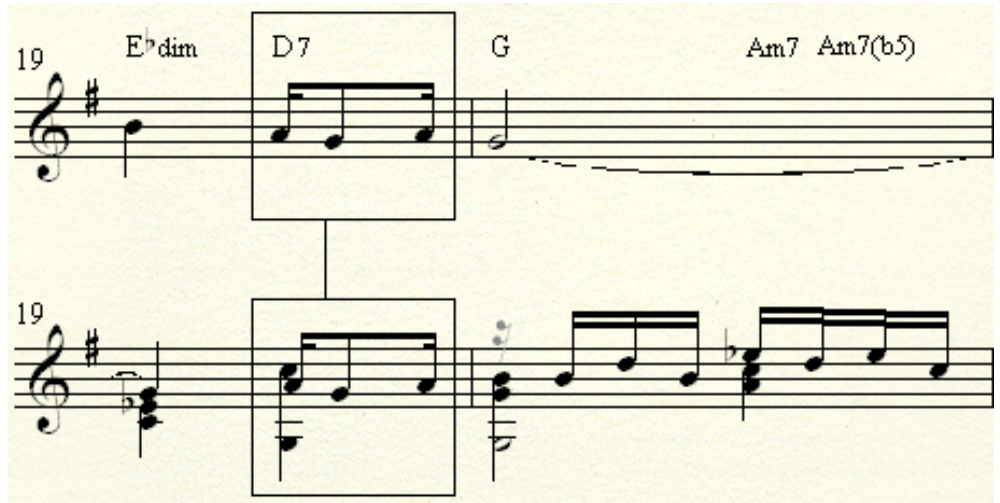

Exemplo musical 37. Mudanças na harmonia.

32 Outra possibilidade de analisar este acorde no arranjo poderia ser a sua definição como dominante D7 com pedal na tônica, nota sol, mesmo sem figura da sensivel (fá sustenido), que não está presente. 
No exemplo musical 38, os retângulos mostram apenas uma pequena diferença. $\bigcirc$ arranjo foi harmonizado com o acorde de $A m 7$ (b5), no lugar dos acordes Am7-Am7(b5).

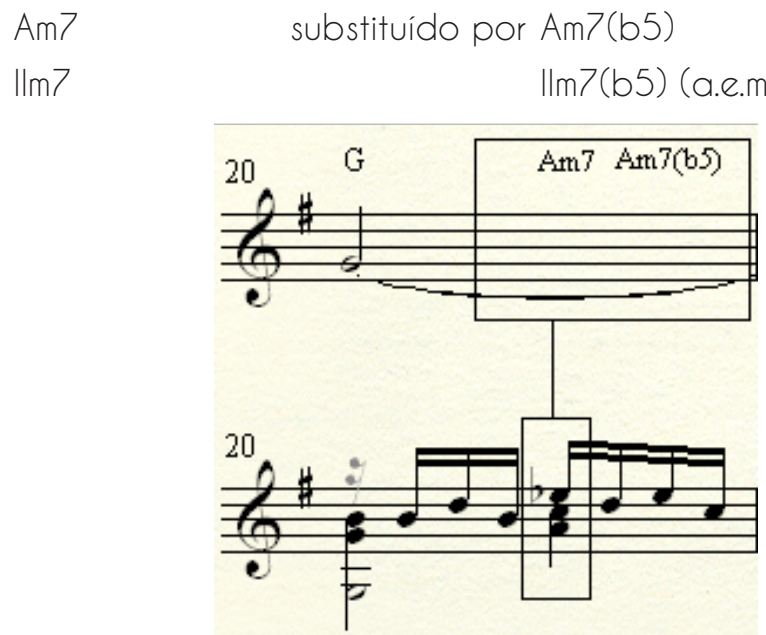

Exemplo musical 38. Mudanças na harmonia.

Exemplo musical 39. $O$ acorde de $C$ substitui o acorde de Bm. Ambos de função tônica.

$\mathrm{Bm} / \mathrm{A} \quad$ substituido por $\mathrm{C}$

IIIm7

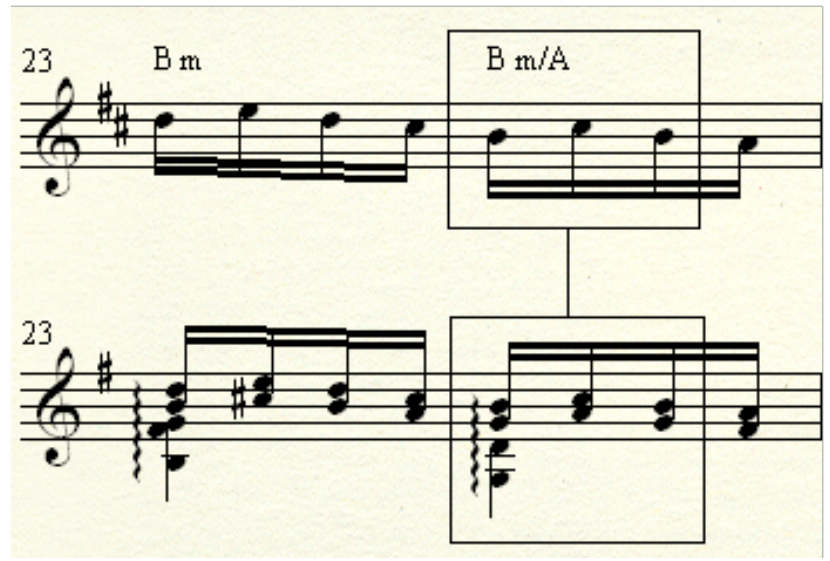

Exemplo musical 39. Mudanças na harmonia. 
No exemplo musical 40, mostramos a progressão harmônica que conduz à volta para a primeira parte. $O$ segundo acorde, de Eb7/Bb, foi substituído pelo acorde de $\mathrm{D}^{0}{ }^{07}$. Ambos são dominantes, mas vinculados a acordes diferentes, como mostram as duas seqüencias onde os acordes estão sublinhados.

$$
\begin{aligned}
& D-\underline{E b 7 / B b}-A m 7-\underline{D 7}-C \\
& D-\underline{D \#} \underline{07}\left(A^{10} 7\right)-\underline{A m / E}-D 7-C
\end{aligned}
$$

Eb7/Bb substituído por D\#07

subV7N

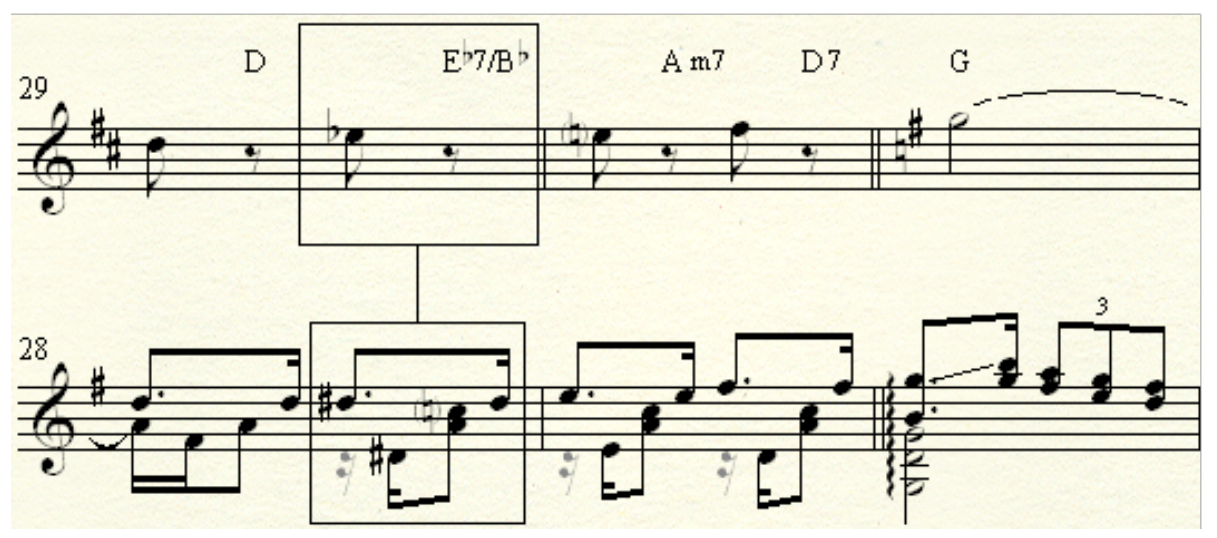

Exemplo musical 40. Mudanças na harmonia.

exemplo musical 41 mostra uma bordadura harmônica. Na partitura de referencia, todo o compasso é harmonizado com o acorde de G. Inserimos a bordadura com o acorde de F\#.

G substituido por C F\# C (bordadura harmônica) 


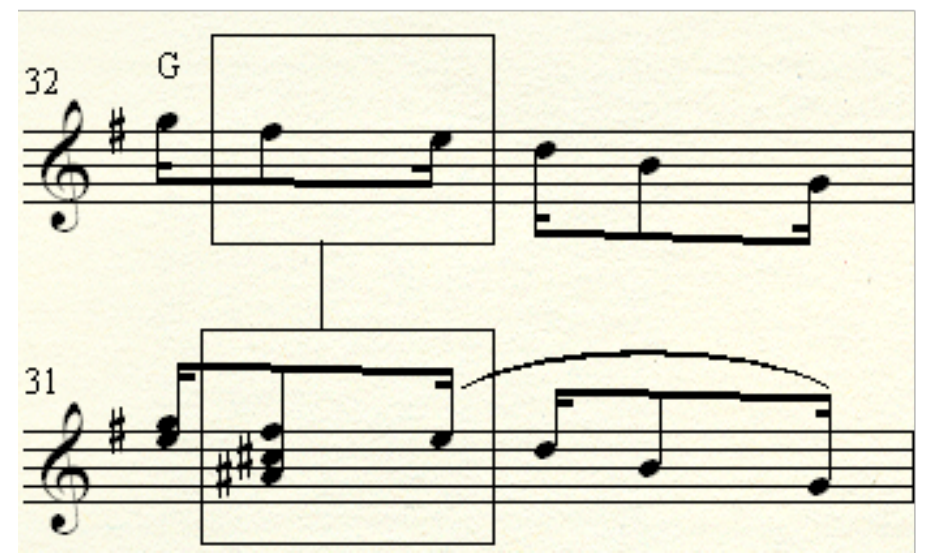

Exemplo musical 41. Mudanças na harmonia.

Exemplo musical 42. $\bigcirc$ acorde de F\#m7(b5) foi substituído pelo acorde arpejado de B7/D\#. Ao observarmos todo o compasso, podemos perceber o movimento cadencial $I \mathrm{~m} 7(\mathrm{~b} 5)-\mathrm{V} 7$. No arranjo, suprimimos o acorde $\| \mathrm{m} 7(\mathrm{~b} 5)$, deixando todo o compasso harmonizado com o acorde dominante.

$$
\begin{array}{rr}
F \# m 7(b 5) & \text { substituido por } B 7 / D \# \\
V \| l m 7(b 5) & V 7 / \mathrm{NIm}
\end{array}
$$

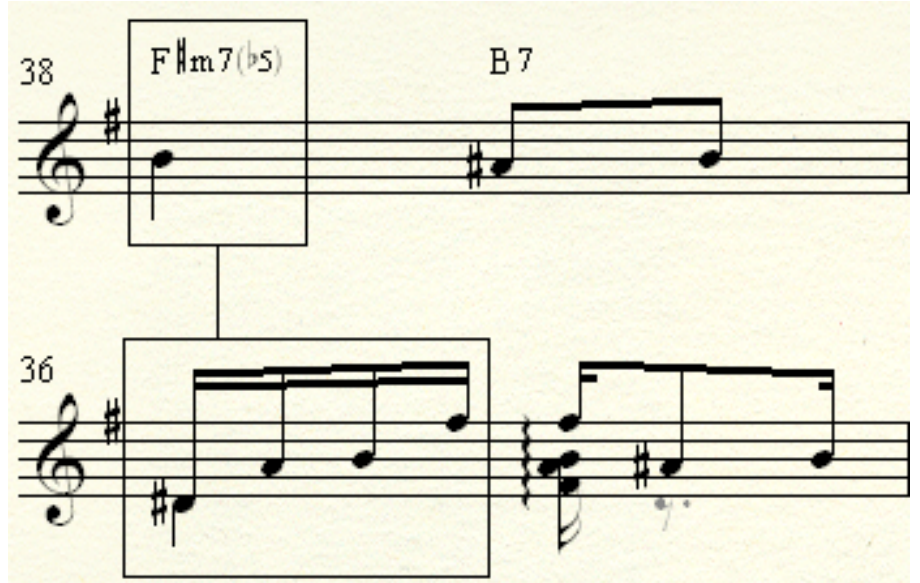

Exemplo musical 42. Mudanças na harmonia. 
O exemplo musical 43 revela duas mudanças. Na primeira, o acorde de $\mathrm{C} / \mathrm{F}$ substitui o acorde de $\mathrm{C}^{\circ}$. Na segunda, o acorde de C(\#5)/E aparece no lugar do acorde de Am.

\begin{tabular}{|c|c|}
\hline $\mathrm{C} \#^{\circ}$ & substituído por G7/F \\
\hline $\mathrm{V} /\left\|^{\circ} /\right\| \mathrm{m}$ & $V 7 / \mathrm{V}$ \\
\hline $\mathrm{Am}$ & substituído por C(\#5) \\
\hline & $\mathrm{IV}(\# 5)$ \\
\hline
\end{tabular}

A condução harmônica original mostra o acorde dominante G\# ${ }^{\circ}$ resolvendo em Am. No arranjo, a substituição do acorde diminuto pelo acorde $\mathrm{C} / \mathrm{F}$ indica o movimento harmônico para $\mathrm{C}$, que se confirma, mas com a quinta aumentada (que aparece somente no arpejo) dando-lhe um caráter suspensivo.

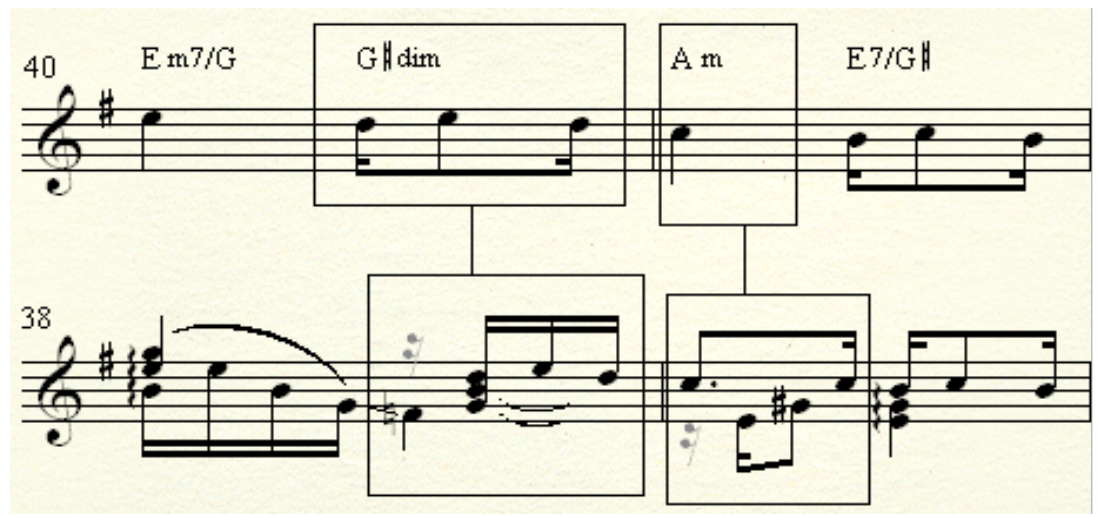

Exemplo musical 43. Mudanças na harmonia.

$\bigcirc$ último exemplo trata da parte final da música - a coda. Pela observação do exemplo musical 44, constata-se que a forma como ela está apresentada no arranjo é totalmente diferente da partitura de referência. Mais adiante, falaremos ainda um pouco mais dessa mudança quando formos comentar a forma musical (item 4). Com relação à harmonia entre as duas partituras, há uma mudança acentuada no arranjo, como consequência do ponto em que se inicia a coda. Na partitura de referência (compasso 45), a melodia mostra um pedal na nota sol com o acompanhamento do acorde de Sol maior (com movimento da quinta), preparando-se para a volta à primeira parte. No arranjo (compasso 43), neste mesmo ponto da música, ocorre o início da coda. Ela 
compõe-se, basicamente, de uma progressão descendente em arpejos de acordes diminutos, pontuada por dois acordes de Sol maior: $C_{-}$- B $-B b^{0}-A^{\circ} .-C-C \#^{\circ}-C^{\circ}-F \#^{\circ}(D 7)-C$.

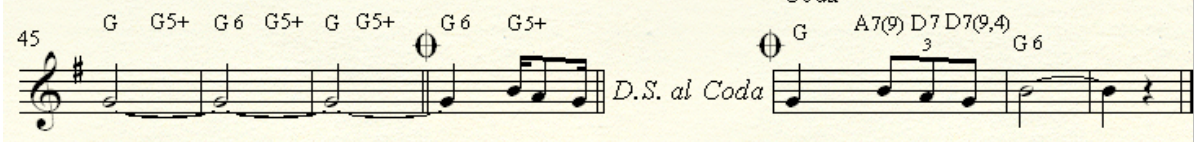

Coda

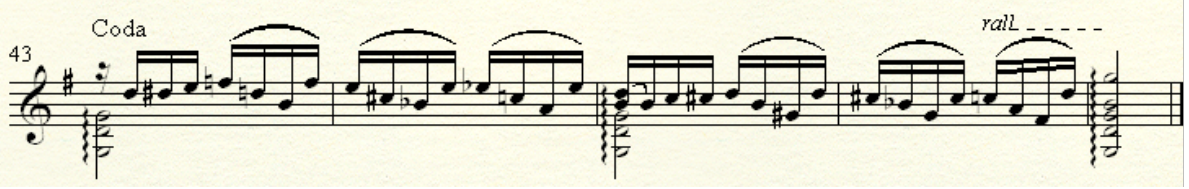

Exemplo musical 44. Mudanças na harmonia.

Resumo das mudanças harmônicas

\begin{tabular}{|c|c|}
\hline$A 7(9)$ & substituído por $\mathrm{C}^{07}{ }^{07}$ \\
\hline V7N & $V \| 107 N$ \\
\hline D7 & substituido por F\#m(b5)/C \\
\hline V7 & VIIm(b5) \\
\hline Cm6 & substituído por $A m 7(b 5) / C$ \\
\hline IVm6 (a.e.m.) ${ }^{33}$ & $\| m 7(b 5)$ (a.e.m.) \\
\hline $\mathrm{Bm}$ & substituido por Bm/C \\
\hline$\| \mid m$ & $\| I m(I)$ \\
\hline Bm6 & substituído por B7 \\
\hline |llm6 & V7NIm \\
\hline
\end{tabular}

33 Acordes de empréstimo modal, são acordes emprestados da tonalidade homônima menor.

\section{7}


$B^{\circ}$

$\mathrm{V} / \mathbb{P}^{\circ} / \mathrm{m}$

A7(9)

VN

$\mathrm{Eb} \times 7$

$b \mid 10^{0} 7$

Am7

IIm7

D7

V7

$\mathrm{Bm} / \mathrm{A}$

$|1| \mathrm{m} 7$

$\mathrm{Eb} 7 / \mathrm{Bb}$

subV7N

C

|

$\mathrm{F} \# \mathrm{~m} 7(\mathrm{~b} 5)$

VIIm7(b5)

C\#०

$\mathrm{V}\left\|{ }^{\circ} /\right\| \mathrm{m}$

Am

$\| m$ substituído por E/C\#

$\mathrm{V} / \| \mathrm{m}$

substituído por $C$

substituído por $\mathrm{Cm}$

IVm (a.e.m.)

substituido por $A m 7(b 5)$

$\| m 7$ (b5) (a.e.m.)

substituído por $\mathrm{C}(4,9)$ ou D7/C

I ou $\underline{V 7 / 1}$

substituido por $C$

substituido por $D \#^{07}$

$b \vee 107$

substituído por C F\# C (bordadura harmônica)

।

substituido por B7/D\#

V7NIm

substituido por G7/F

V7/IV

substituído por C(\#5)/E

IV(\#5)

\section{8}




\section{3) Referências extra-partitura}

Já mencionamos que, em um grande número de partituras de Choro, escritas para instrumentos melódicos e com acompanhamento cifrado, há lacunas de informações. Na execução dessas obras, espera-se que o intérprete esteja de posse de tais informações, para que possa realizar de forma "correta" a interpretação. Elaboramos o arranjo de forma que pudessem ser notadas na partitura algumas dessas informações, que denominamos de referências extra-partitura, e que passaremos agora a comentar.

Dentre as referencias inseridas no arranjo, destacamos duas que não estão notadas na partitura de referência. A primeira, mostrada no exemplo musical 45, é o acompanhamento da melodia principal por um contracanto característico em arpejos. A segunda referência, no exemplo musical 46, é a coda.

Exemplo musical 45. Acompanhamento em arpejos com movimentação da quinta do acorde.
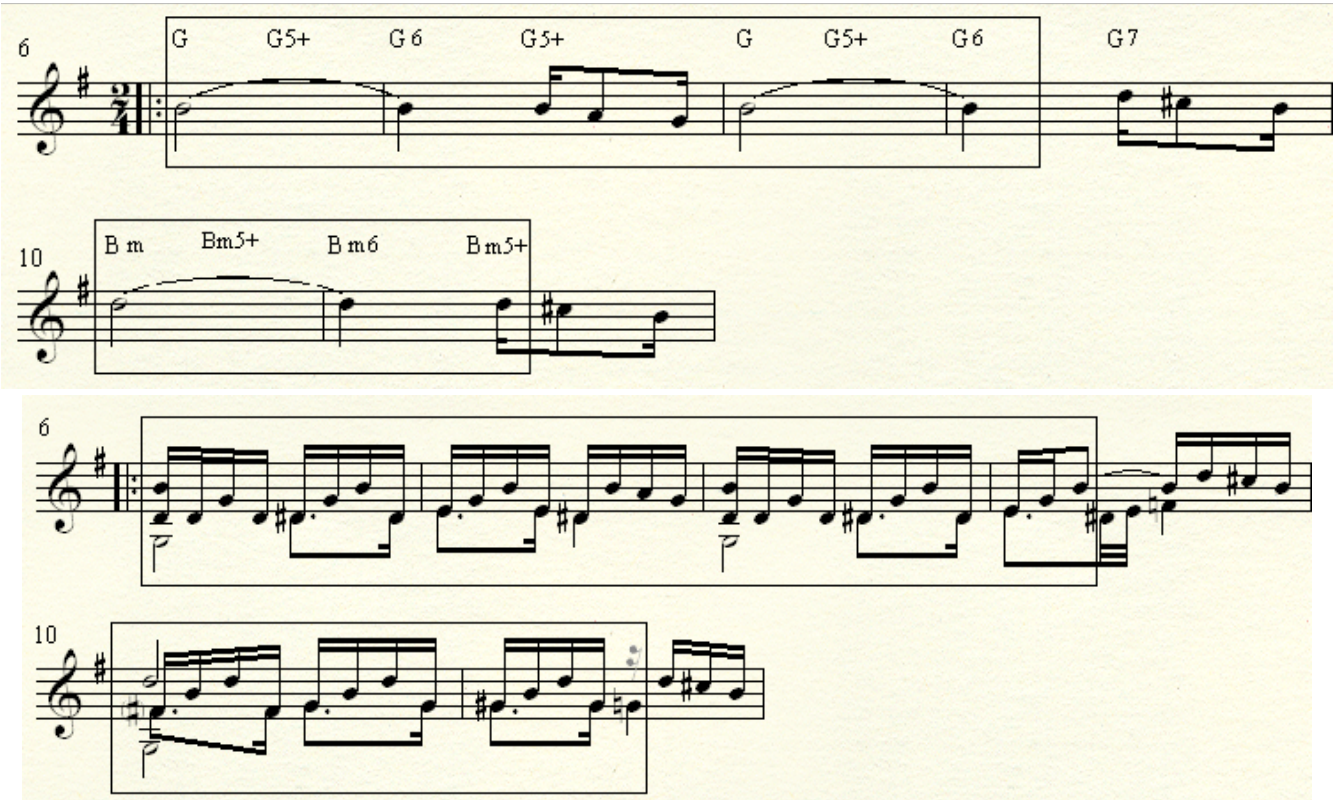

Exemplo musical 45. Referências extra-partitura. 
Exemplo musical 46. A coda, formada por uma progressão de acordes diminutos arpejados.
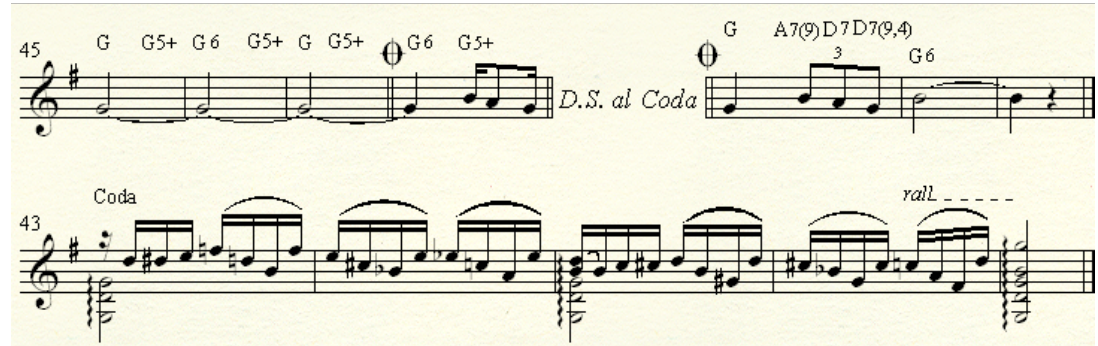

Exemplo musical 46. Referências extra-partitura.

Uma das características que formam o Choro é a liberdade que o intérprete tem para a execução de contracantos junto à melodia. $\bigcirc$ violão de 7 cordas é o instrumento contrapontístico por excelência que realiza a chamada "baixaria" - contracantos na região média e grave do instrumento. Utilizamo-nos desta característica contrapontística em algumas passagens, sempre em trechos nos quais a melodia apresentava repouso sobre nota longa ou pausa. Os exemplos musicais 47, 48, 49, 50, 51 , 52 e 53, ilustram essa utilização do contraponto.

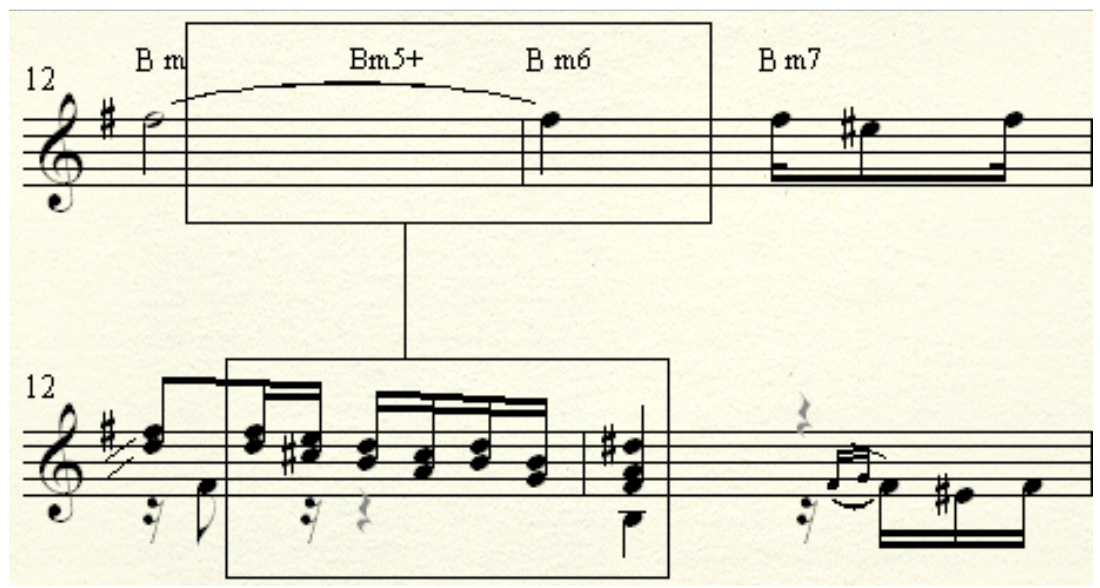

Exemplo musical 47. Referências extra-partitura. 


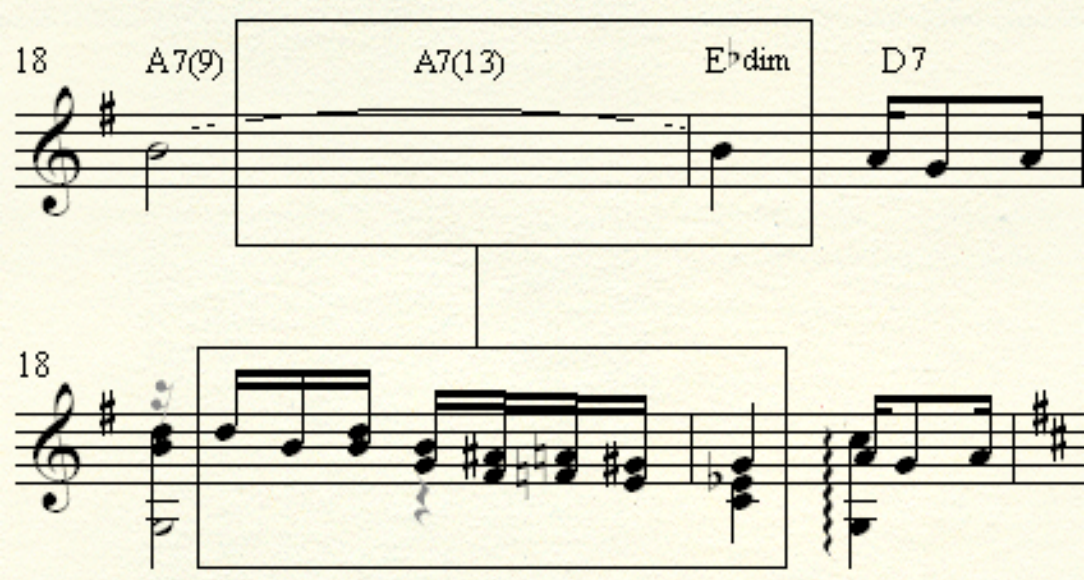

Exemplo musical 48. Referências extra-partitura

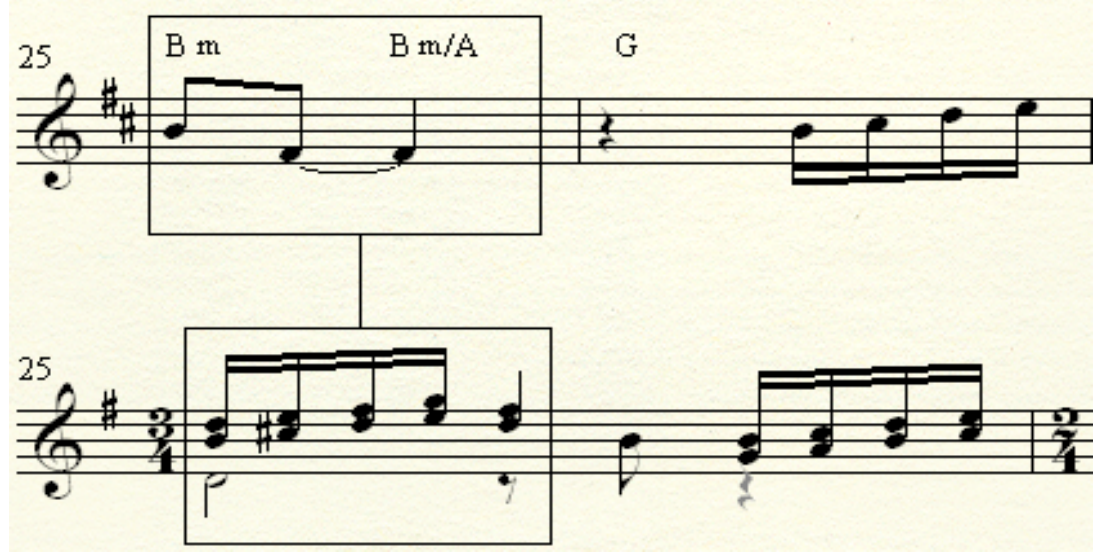

Exemplo musical 49. Referências extra-partitura 


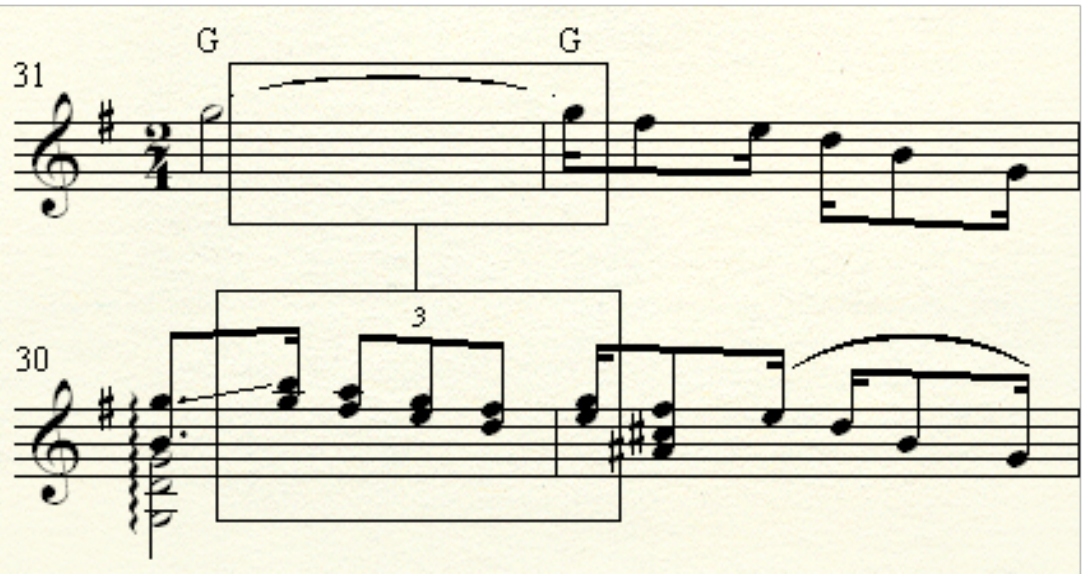

Exemplo musical 50. Referências extra-partitura.

No exemplo musical 51, o primeiro trecho, destacado pelos retângulos, mostra a única vez em que a melodia foi suprimida para a entrada da "baixaria", transposta uma oitava acima. A nota "ré" da melodia não é tocada.

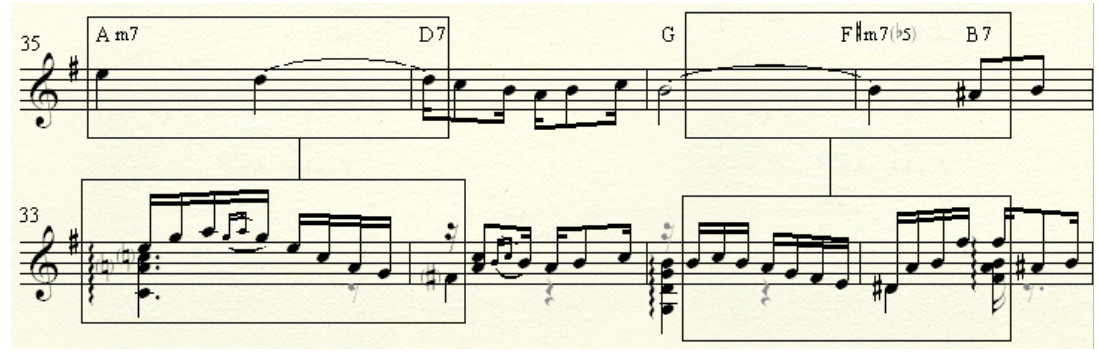

Exemplo musical 51. Referências extra-partitura. 




Exemplo musical 52. Referências extra-partitura.

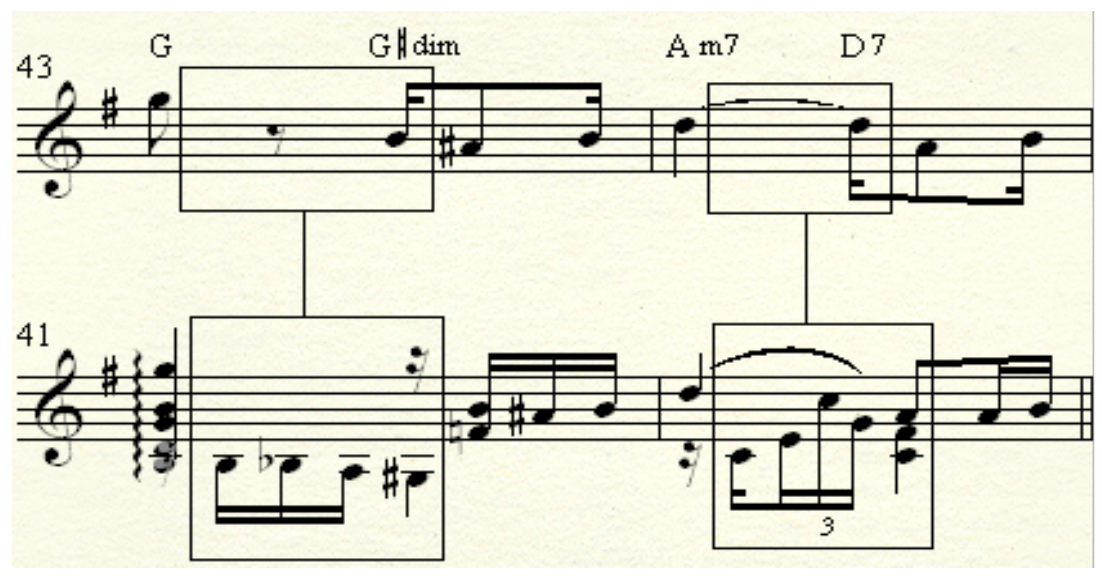

Exemplo musical 53. Referencias extra-partitura.

\section{4) Forma}

No Choro com três partes, a forma apresenta o seguinte esquema - AABBACCA. O Choro "Carinhoso" tem duas partes e seu esquema formal apresenta-se como AABBAcoda. $O$ fato de ter apenas duas partes fez com que Pixinguinha o mantivesse "na gaveta" por muitos anos, pois naquela época, os Choros normalmente apresentavam três partes. Neste arranjo para viola solo, mudamos a forma para AABcoda, sem a

\section{3}


repetição da segunda parte e sem a volta para a primeira parte, indo direto da segunda parte para a coda. Neste ponto, tomamos a liberdade de utilizar um final diferente da partitura de referencia, comentado também no item 3 (Referências extra-partitura). No exemplo musical 54, que será mostrado a seguir, a coda não traz qualquer ligação com a partitura de referência. A coda desta partitura compõe-se apenas de três compassos, 49 a 51.

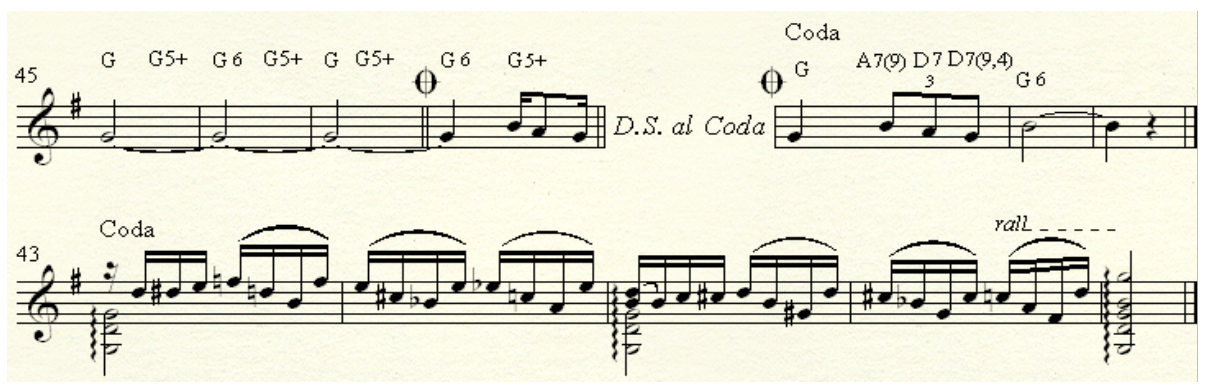

Exemplo musical 54. Forma.

5) Técnica

Não há dificuldade técnica acentuada ${ }^{34}$. $\bigcirc$ andamento é lento e um pouco rubato. Há exigência de independência e de extensão entre os dedos da mão esquerda em alguns poucos trechos com trabalho contrapontístico. Com relação à mão direita, o arranjo foi feito para ser tocado inteiramente com o polegar, com movimento para baixo. Assim, o intérprete deve ter uma prática de movimento de polegar em todas as cordas.

34 Sabemos que essa questão é um tanto subjetiva. 


\section{CONSIDERAÇÕES FINAIS}

É importante destacar que este artigo é fruto de um produto artístico, da criação do arranjo. Estudamos parte desta produção artística por meio da análise musical, na qual demonstramos uma série de soluções harmônicas, rítmicas, melódicas, formais e técnicas, que foram utilizadas e, a seguir, teceremos comentários sobre as mais significativas.

Em geral, no Choro a melodia é o fio condutor da obra. Alterações sobre ela devem ser feitas com cuidado. $\bigcirc$ arranjo de Carinhoso mostrou níveis de interferência acentuados. Permitimo-nos essa liberdade porque a obra é muito conhecida. Assim, a inclusão de uma série de alterações como contracantos, dobramentos em terças e sextas, alterações rítmicas diversas, contrações, e até a omissão da linha melódica em um pequenino trecho, não descaracterizaram a obra, ao contrário. Neste caso, o arranjo ganhou em interesse e qualidade.

Um dos itens que exigiram mais cuidados no arranjo foi o da harmonia. Dois pontos devem ser destacados como síntese: a montagem dos acordes e os tipos de acompanhamento. $\bigcirc$ arranjo de Carinhoso trouxe uma harmonização mais moderna, com a utilização de acordes com sétima e nona, menores com sexta, menores com quinta diminuta e sétima, com quarta e nona, e várias inversões. A utilização destes acordes na viola demonstrou que é perfeitamente possível realizar no instrumento uma harmonia que vá além da tríade maior, menor, diminuta e dominante com sétima.

A questão do nível técnico é subjetiva e difícil de ser avaliada. De um modo geral, o nível de exigência requerido pode ser considerado como médio. Não é para iniciantes, mas também não exige uma técnica apuradissima no nível de um intérprete virtuose.

Sobre a mão direita, observamos que o polegar destacou-se como um dedo importante. É possivel a interpretação com a utilização dos outros dedos, mas a qualidade tímbrica não teria o mesmo resultado. A questão do equilibrio sonoro deve ser mencionado porque é exigido do intérprete um trabalho de independência na aplicação do peso sobre as cordas.

A proposta de inserção da viola no Choro desenvolveu-se em dois momentos. Num primeiro momento, buscamos o estabelecimento de

\section{5}


uma afinidade musical entre ambos por meio do arranjo e, em seguida, utilizando-se da análise, procuramos discutir mais detalhadamente, aspectos do arranjo que corroborassem o resultado obtido.

A proposta inicial foi respondida de forma contundente pela própria produção do arranjo, não deixando dúvidas com relação à afirmação de que existe uma afinidade musical. Dessa afirmação, concluímos que o fato de a viola não ter sido utilizada como base instrumental do Choro, juntamente com o violão e o cavaquinho, nem como instrumento solista, não está ligado a questões musicais, seja de incompatibilidade estilística ou técnica.

A análise do arranjo demonstrou de forma clara particularidades da viola, principalmente no que diz respeito à adequação desse instrumento às construções melódicas, rítmicas e harmônicas típicas do Choro, atuando como instrumento solista desse gênero.

Temos consciência de que a possibilidade de extensão da análise a outros arranjos poderá levantar novas questões, agregando mais informações. Esperamos dar continuidade ao que foi aqui apresentado produzindo um número maior de arranjos com as respectivas análises. Estamos convictos de que a elaboração de arranjos solo de Choros aponta para um caminho a ser amplamente explorado e perfeitamente possivel de ser trilhado - conquistar mais uma possibilidade musical para a viola.

\section{REFERÊNCIAS}

ALENCAR, Edgar de. $O$ fabuloso e harmonioso Pixinguinha. Rio de Janeiro: Cátedra; Brasília: INL, 1979.

ANDRADE, Ayres de. Francisco Manuel da Silva e seu tempo. Volume I - Coleção Sala Cecília Meireles, Rio de Janeiro, 1963.

ANDRADE, Mário de. Ensaio sobre a música brasileira. $3^{a}$ ed. São Paulo: Livraria Martins Editora S.A.; Brasilia: Instituto Nacional do Livro/ MEC, 1972.

Modinhas Imperiais. Belo Horizonte: Editora Itatiaia, 1980.

\section{6}

REV. TULHA, RIBEIRÃO PRETO, v. 2, n. 2, p. 94-153, jul.-dez. 2016 
ARAÚjo, Rui Torneze de. Viola caipira: estudo dirigido. São Paulo: Irmãos Vitale, 1999.

ARAÚjO, Mozart de. A Modinha e o Lundu no século XVIII. São Paulo: Ricordi Brasileira, 1963.

ARRANJEMENT. In: SADIE, Stanley. The New CROVE Dictionary of Music and Musicians. Macmillan Publishers Limited, 1980, p.627.

BARBEITAS, Flavio T. Reflexões sobre a prática da transcrição: as suas relações com a interpretação na música e na poesia. PER MUSI, v.l, p.89-97, 2000.

BENT, lan. Analisys. New York: W.U.Norton \& Company, 1987. 1997.

BRACA, Sebastião. O lendário Pixinguinha. Niterói: Muiraquitã,

CARNEIRO, Josimar Machado Comes Carneiro. A baixaria no Choro. 200 1. Dissertação (Mestrado em Música) Centro de Letras e Artes, Universidade Federal do Estado do Rio de Janeiro.

CARRASQUEIRA, Maria José. O Melhor de Pixinguinha: melodias e cifras. São Paulo: Irmãos Vitale, 1997.

CASTRO, Renato Moreira Varoni de. Os caminhos da viola no Rio de Janeiro do século XIX. 2007. Dissertação (Mestrado em Música) Escola de Música, Universidade Federal do Rio de Janeiro.

CHEDIAK, Almir. Dicionário de Acordes Cifrados: harmonia aplicada à música popular. $2^{\mathfrak{a}}$ ed. São Paulo: Irmãos Vitale S/A, 1984.

CORREA, Roberto. Viola Caipira. Brasília, MusiMed, 1983. A arte de Pontear Viola. Brasilia, Curitiba: ed. autor, 2000.

DECHI, Fernando. Viola brasileira e suas possibilidades. São Bernardo do Campo: Violeiro Andante, 2001.

\section{7}


FERRER, Marcus de Araújo. Suite Retratos e Choros IV: o Choro visto por Radamés Gnattali e Heitor Villa-Lobos. 1996. Dissertação (Mestrado em Música) Escola de Música, Universidade Federal do Rio de Janeiro.

CUEST, Ian. Arranjo: método prático. Rio de Janeiro: Lumiar editora, V.1-2-3, 1996.

LESTER, Joel. Performance and analysis: interaction and interpretation. In: RINK, John (org.). The practice of performance: studies in musical interpretation. London: Cambridge University Press, 1995. p. 197-2 16.

MACALHÃES, Alexandre Caldi. Contracantos de Pixinguinha: contribuições históricas e analíticas para a caracterização do estilo. 2000. Dissertação (Mestrado em Música) Centro de Letras e Artes, Universidade Federal do Estado do Rio de Janeiro.

MOURA, Reis e FREITAS, Marcos Villaça. Descomplicando a viola. Brasilia: ed: Autor, 2000.

PIRES, Luciano Linhares. Dilermando Reis: o violonista brasileiro e suas composições. 1995. Dissertação (Mestrado em Música) Escola de Música, Universidade Federal do Rio de Janeiro.

SÁ, Paulo Henrique Loureiro de. Receita de Choro ao molho de bandolim: uma reflexão acerca do Choro e sua forma de criação. 1999. Dissertação (Mestrado em Música) Centro de Pós-Graduação, Pesquisa e Extensão, Conservatório Brasileiro de Música.

SALEK, Eliane Corrêa. A flexibilidade rítmico-melodica na interpretação do Choro e sua forma de criação. 1999. Dissertação (Mestrado em Música) Centro de Letras e Artes, Universidade Federal do Estado do Rio de Janeiro.

SĖVE, Mário. Vocabulario do Choro: estudos e improvisos. Rio de Janeiro: Lumiar editora, 1999.

SILVA, Marilia Trindade Barbosa da; OLIVEIRA FILHO, Arthur Loureiro de. Filho de Ogum bexiguento. Rio de Janeiro: FUNARTE, 1979. 1979.

SIQUEIRA, Baptista. Modinhas do passado. Rio de Janeiro: [s.e.],

\section{8}


SOUZA, Andréa Carneiro. Do sertão para as salas de concerto: Viola - um processo de ensino e aprendizado. 2002. Dissertação (Mestrado em Música) Centro de Letras e Artes, Universidade Federal do Estado do Rio de Janeiro.

\section{5. \\ Viola Instrumental Brasileira. Rio de Janeiro: ARTVIVA Editora,}

TINHORÃO, José Ramos. Música popular de Indios, Negros e Mestiços. $2^{\circ}$ ed. Petrópolis: Editora Vozes Ltda, 1975.

Pequena Historia da Música Popular - da Modinha a Canção de Protesto. Petrópolis: Editora Vozes Ltda, 1974.

VERZONI, Marcelo Oliveira. Os primórdios do choro no Rio de Janeiro. 2000. Tese (Doutorado em Música) - Centro de Letras e Artes, Universidade Federal do Estado do Rio de Janeiro.

VIOLA, Braz da. Manual do Violeiro. São Paulo: Ricordi, 1999. Um Toque de Viola. [s.l.]. ed: Autor, [s.d].

\section{Partitura}

VIANNA FILHO, Alfredo da Rocha (Pixinguinha). Carinhoso. São Paulo: Irmãos Vitale S.A, 1947. I partitura ( I p.).

\section{Sobre o autor}

Marcus Ferrer. Prof.Dr. da Escola de Música da universidade Federal do Rio de Janeiro. Mestre em Composição e Doutor em Teoria e Prática da Interpretação Musical. Desenvolve trabalho de concertista solo e de câmara; além de projetos de pesquisa relacionados à Viola de 10 cordas e à Arte Sonora.

Aprovado em: 28/03/2017 


\section{Anexo 1 \\ Carinhoso}

Choro Canção

Revisão: Antonio Carlos Carrasqueira

Pixinguinha Cifra: Edmilson Capelupi

letra: João de Barro


O Copyright i 936 by E. S. Mangione - Sao Paulo - Rio de Janeiro - Brasil

Todos os direitos reservacios para lodos os paises. All rights reserved 

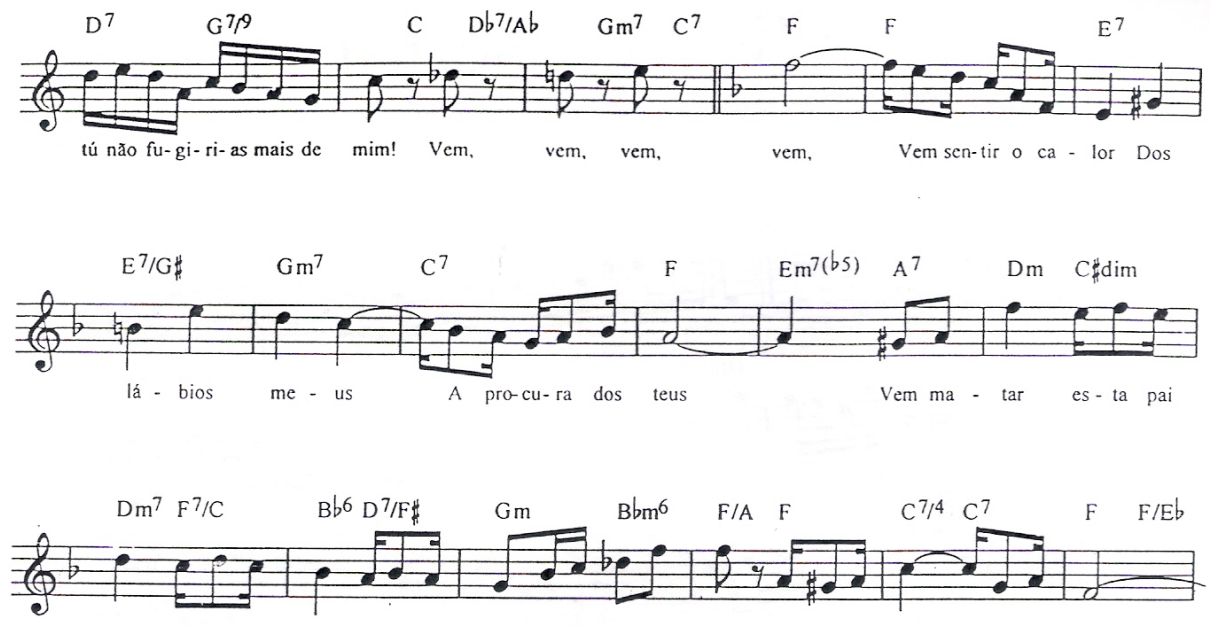

xão Quéme de - vora o co-ra - ção_E só as - sim en - tão, Se - rei fe - liz Bem fe - liz

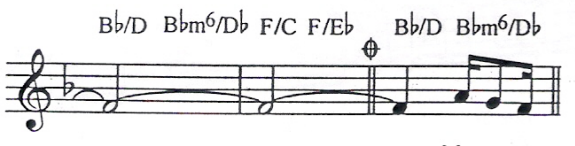

Do $\%$

Meuco-ra

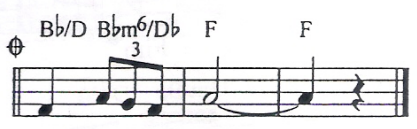

Meu coração

Não Sei porque,

Bate feliz

BIS Quando te vê...

$E$ os meus olhos ficam sorrindo,

E pelas ruas vão te seguindo,

Mas mesmo assim,

Foges de mim!
Ah! se tu soubesses como eu sou tão carinhoso,

E o muito e muito que te quero!...

E como é sincero o meu amor

Eu sei que tu não fugirias mais de mim!

Vem, vem, vem,

Vem sentir o calor

Dos lábios meus

A procura dos teus,

Vem matar esta paixão

Que me devora o coração

E só assim, então,

Serei feliz,

Bern feliz. 


\author{
8. Anexo 2
}

Viola de 10 cordas

Rio Abaixo

Arranjo e digitação

Marcus Ferrer
CARINHOSO

Choro Canção
Alfredo da Rocha Vianna

(Pixinguinha)
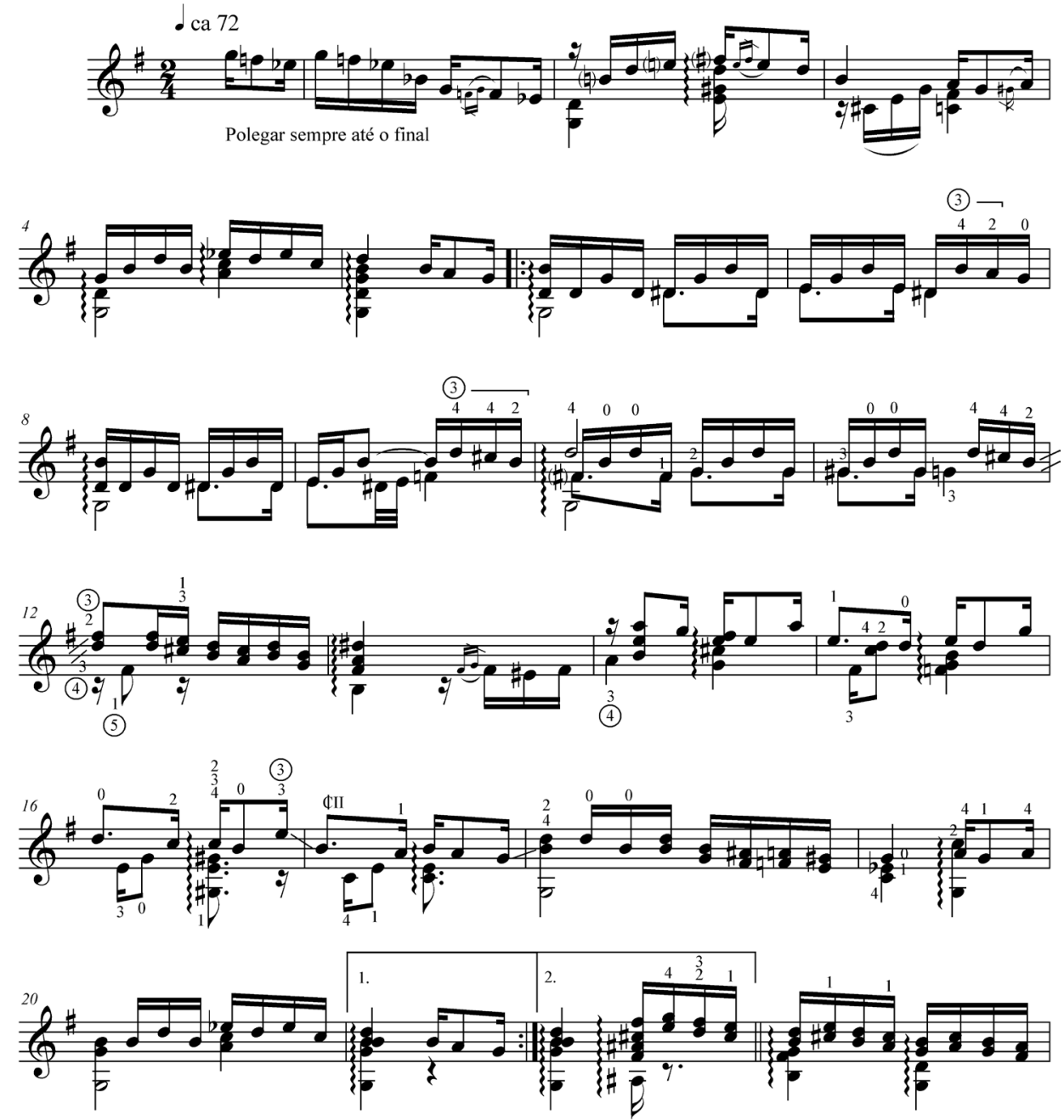

Marcus Ferrer - Doutorado em Música / PPGM / UNIRIO - CAPES / FAPERJ 

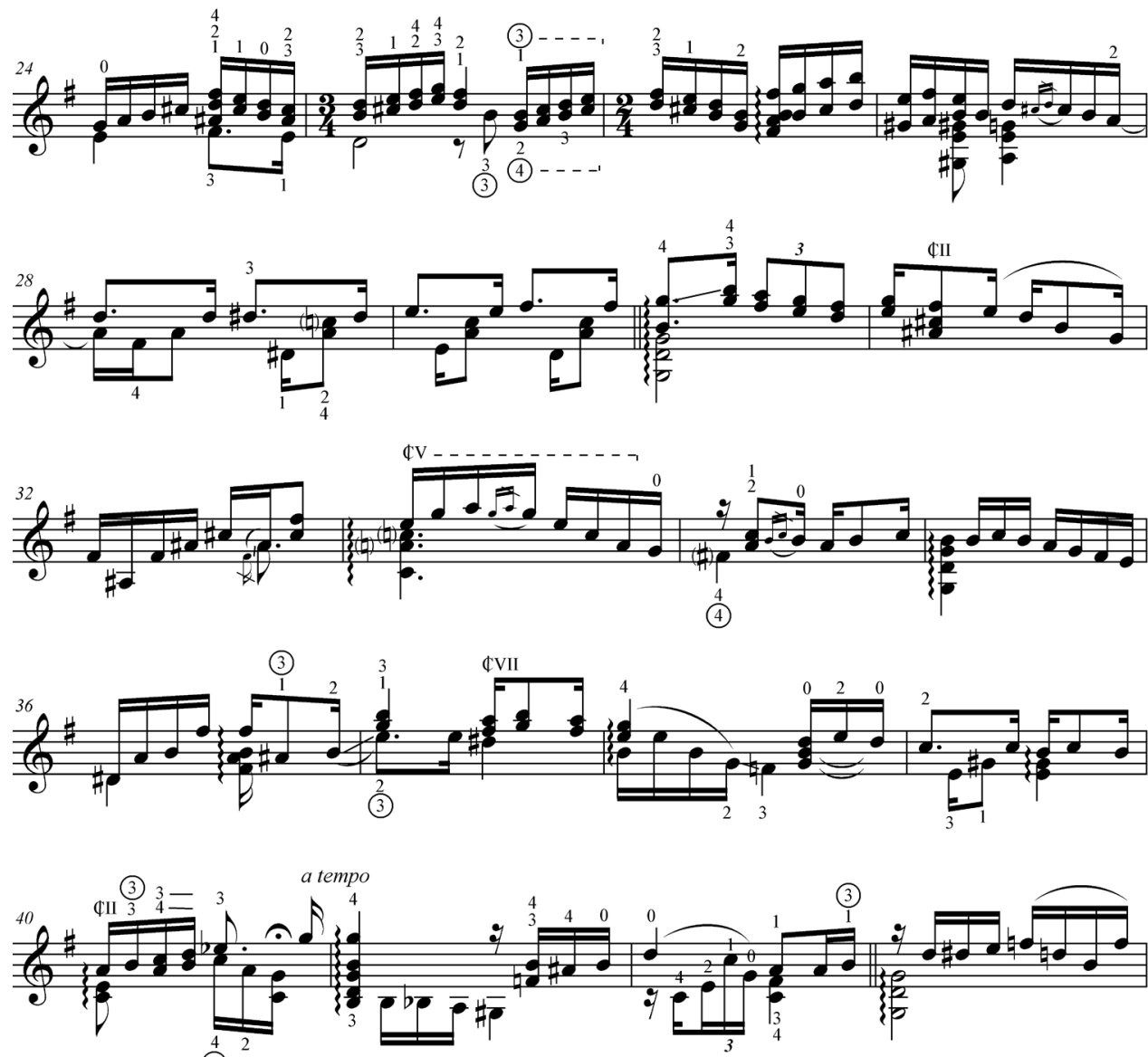

(4) --1

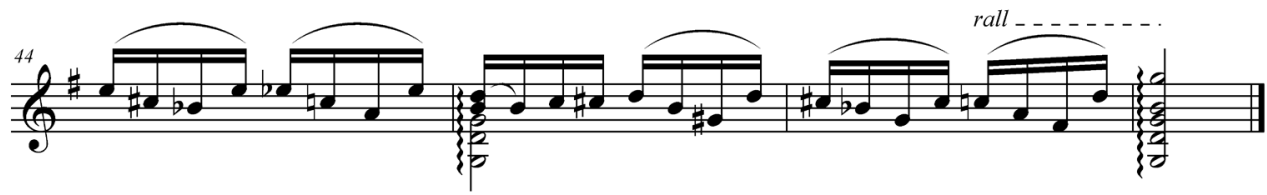

